UNIVERSIDADE FEDERAL FLUMINENSE INSTITUTO DE ARTE E COMUNICAÇÃO SOCIAL DEPARTAMENTO DE CINEMA E AUDIOVISUAL

PEDRO HENRIQUE ALVES SILVA

DIFERENTES FORMAS DE DIZER ADEUS: A MORTE NAS NARRATIVAS INICIÁTICAS 


\section{DIFERENTES FORMAS DE DIZER ADEUS: A MORTE NAS NARRATIVAS INICIÁTICAS}

Trabalho de conclusão de curso apresentado ao curso de Licenciatura em Cinema e Audiovisual, como requisito parcial para conclusão do curso.

Orientador:

Prof. Dr. Rafael de Luna Freire 
Ficha catalográfica automática - SDC/BINF

A474d Alves Silva, Pedro Henrique

Diferentes formas de dizer adeus: a morte nas narrativas iniciáticas / Pedro Henrique Alves Silva ; Rafael de Luna Freire, orientador. Santo Antônio de Pádua, 2018. $69 \mathrm{f}$. : il.

Santo Antônio de Pádua, 2018.

1. Morte na arte. 2. Narrativas Iniciáticas. 3. Protagonistas Infantis. 4. Amadurecimento.| 5. Produção intelectual. I. Título II. Freire, Rafael de Luna, orientador. III. Universidade Federal Fluminense.

$\mathrm{CDD}-$ 
DIFERENTES FORMAS DE DIZER ADEUS: A MORTE NAS NARRATIVAS INICIÁTICAS

Trabalho de conclusão de curso apresentado ao curso de Licenciatura em Cinema e Audiovisual, como requisito parcial para conclusão do curso.

Aprovada em 06 de dezembro de 2018.

BANCA EXAMINADORA

Prof. Dr. Rafael de Luna Freire (Orientador)

Universidade Federal Fluminense

Prof. Dr. Antônio do Nascimento Moreno

Universidade Federal Fluminense

Prof $^{\mathrm{a}}$. Dra ${ }^{\mathrm{a}}$. India Mara Martins

Universidade Federal Fluminense 
TRABALHO DE CONCLUSÃO DE CURSO (TCC)

Instituto de Arte e Comunicação Social

Departamento de Cinema e Vídeo

PARECER DA BANCA EXAMINADORA

Aluno(a): Pedro Henrique Alves Silva

Matrícula: 114057094

\section{TítULo}

Diferentes formas de dizer adeus: a morte nas narrativas iniciáticas.

BANCA EXAMINADORA

\begin{tabular}{|l|l|}
\hline Prof. Orientador & Dr. Rafael de Luna Freire \\
\hline Examinador 1 & Dr. Antônio do Nascimento Moreno \\
\hline Examinador 2 & Dra. India Mara Martins \\
\hline
\end{tabular}

\section{PARECER}

A banca elogia o trabalho, destacando a escolha cuidadosa dos filmes, a perspectiva original sobre un tema pouco estudado - a morte e a inföncia en narrativas iniciáticas - e o capricho e fluência no texto e apresentagāo, recomendando a contimidode da pesquisa no âmbito da pós-graduagāo

DATA: $6 / 12 / 18$ NOTA FINAL: 10,0 (Dez)

\begin{tabular}{|l|l|}
\hline \multicolumn{2}{|c|}{ ASSINATURAS DA BANCA } \\
\hline Prof. Orientador & Relal de foforgecy. \\
\hline Examinador 1 & Exefor \\
\hline Examinador 2 & \\
\hline
\end{tabular}


A todos os filmes que salvaram a minha vida. 


\section{AGRADECIMENTOS}

Não poderia começar de outra maneira que não seja essa: agradecendo o apoio de minha mãe, Margarete Alves, e de meu padrasto, Edilberto Batista. Sem a contribuição deles, eu nunca conseguiria ter concluído minha graduação e concretizado muitos de meus projetos — se não, todos!

Outra pessoa que sempre me acompanhou durante minha trajetória foi Lua Guerreiro, melhor amiga que alguém pode desejar e que esteve presente durante toda minha formação — do dia da matrícula até as produções dos curtas-metragens que participei.

No ambiente universitário, conheci várias pessoas que contribuíram de formas singulares para minha trajetória acadêmica. Quero agradecer nomeadamente a Barbara Beznosai que me apaixonou pelo seu amor aos filmes de terror e por sua personalidade; Bernardo Campbell que compartilhou comigo os melhores momentos da docência com uma turma da Educação Infantil, além de várias partidas de jogos de tabuleiro; Lariza Relvas que foi minha parceira no PIBID e em incontáveis viagens de ônibus para a Gávea; Mariana Revoredo que partilhou comigo momentos importantíssimos da graduação e sempre será minha paulistana favorita; Tatiana Delgado, dona do melhor abraço, que comprovou para mim que dança contemporânea pode ser bem divertida; e Thereza Levenhagen que foi responsável por transformar meu tempo livre em uma sitcom ambientada metade em seu apartamento, Marte, e metade no "nosso bar".

Ainda na Universidade Federal Fluminense, tive o prazer de conhecer ótimos docentes que corroboraram com minha escolha certa de curso: Eliany Salvatierra que me orientou como ninguém durante a minha iniciação a docência e também fora dela; Fabián Núñez que aprofundou meus conhecimentos na cinematografia mundial e criou em mim a paixão por filmes latino-americanos; Índia Mara Martins que aceitou um grupo de alunos do segundo período de licenciatura em sua matéria, ajudou-os e, com isso, permitiu que meu primeiro filme fosse realizado; Mariana Baltar que colaborou ativamente para o desenvolvimento dessa monografia e me brindou com uma parceria maravilhosa durante meu período como monitor; e Rafael de Luna que aceitou o meu convite de orientação e foi responsável por uma das melhores aulas que vi — onde assisti Cordão de Ouro (1977) de Antonio Carlos da Fontoura pela primeira vez. Cada um deles demonstrou a importância do ambiente universitário pra mim, além de 
resistirem frente ao sucateamento do ensino público. Minha monografia não seria a mesma sem os ensinamentos transmitidos por cada um deles. 
As crianças têm muitas percepções que não podem traduzir em palavras; sua visão é sempre muito mais rica, sua apreensão é constantemente mais forte do que seu vocabulário imediato ou não.

Henry James 


\section{RESUMO}

O presente trabalho se propõe analisar as diferentes representações da morte em filmes protagonizados por personagens infantis, buscando entender melhor a relação existente entre essa ferramenta narrativa e o amadurecimento dos personagens principais. Partindo do termo "narrativas iniciáticas", cunhado pelo autor José de Souza Miguel Lopes, divido as análises em três grupos: $\mathrm{O}$ fim da inocência, onde analiso o primeiro encontro com a morte em Conta Comigo, de Rob Reiner, e Meu Primeiro Amor, de Howard Zief; A crueldade infantil na assimilação da violência, onde reflito sobre a crueldade infantil em Brinquedo Proibido, de René Clément, e Deixa Ela Entrar, de Tomas Alfredson; e $\mathrm{O}$ suicídio como anti-narrativa iniciática, onde discorro sobre a decisão de pôr fim a própria vida em Alemanha, Ano Zero, de Roberto Rossellini, e O Porco Espinho, de Mona Achache. Através da análise fílmica destas obras partindo de teorias de ritos de passagem, morte, infância e cinema de autores como Arnold Van Gennep, Victor Turner, Vicky Lebeau, Bert Cardullo, Monica Flegel e outros, as variadas facetas da morte existentes nas obras, assim como a estrutura das narrativas iniciáticas, são avaliadas.

Palavras-chave: Narrativas Iniciáticas. Protagonistas Infantis. Morte. Amadurecimento. 


\begin{abstract}
The present work aims to analyze the different representations of death in films featuring child protagonists, seeking to better understand the connexion between the narrative tool and the coming of age of the main characters. Starting from the term "initiatory narratives" developed by the author José de Souza Miguel Lopes, I divide the analysis into three groups: The End of Innocence, where I analyze the first encounter with death in Rob Reiner's Stand By Me and Zief Howard's My Girl; Child cruelty in the assimilation of violence, where I reflect on child cruelty in René Clément's Forbidden Games and Tomas Alfredson's Let the Right One In; and Suicide as an contradiction to the initiatory narrative, where I discuss the decision of the protagonist killing himself in Roberto Rossellini's Germany, Year Zero and Mona Achache's The Hedgehog. Through the film analysis of these works starting from the theories of rites of passage, death, childhood and cinema of authors such as Arnold Van Gennep, Victor Turner, Vicky Lebeau, Bert Cardullo, Monica Flegel and others, the various facets of death in the works, as well as the structure of the initiatory narratives, are evaluated.
\end{abstract}

Keywords: Initiatory Narratives. Child Protagonists. Death. Coming of Age. 


\section{RESUMEN}

El presente trabajo se propone analizar las diferentes representaciones de la muerte en películas protagonizadas por personajes infantiles, buscando entender mejor la relación existente entre esta herramienta narrativa y la maduración de los personajes principales. A partir de la expresión "narrativas iniciáticas", acuñado por el autor José de Souza Miguel Lopes, yo divido las análisis en tres grupos: El fin de la inocencia, donde investigo el primer encuentro con la muerte en Cuenta Conmigo, de Rob Reiner, y Mi chica, de Howard Zief; La crueldad infantil en la asimilación de la violencia, donde reflexiono sobre la crueldad infantil en Juegos Prohibidos, de René Clément, y Déjame entrar, de Tomas Alfredson; y el suicidio como anti-narrativa iniciática, donde yo escribo sobre la decisión de poner fin a la propia vida en Alemania, Año Cero, de Roberto Rossellini, y El erizo, de Mona Achache. A través de la análisis fílmica de estas obras partiendo de teorías de ritos de pasaje, muerte, infancia y cine - de autores como Arnold Van Gennep, Victor Turner, Vicky Lebeau, Bert Cardullo, Monica Flegel y otros, las variadas facetas de la muerte existentes en las obras, así como la estructura de las narrativas iniciáticas, se evalúan.

Palabras-claves: Narrativas Iniciáticas. Protagonistas Infantiles. Muerte. La maduración. 


\section{LISTA DE FIGURAS}

Figura 1 - O protagonista adulto observa dois jovens passarem através da janela do seu carro em 'Conta Comigo'.

Figura 2 - Mais jovem, o protagonista conversa com o pai que se mantém fora do cômodo em 'Conta Comigo'

Figura 3 - O dono do ferro-velho separado das crianças por uma grade em 'Conta

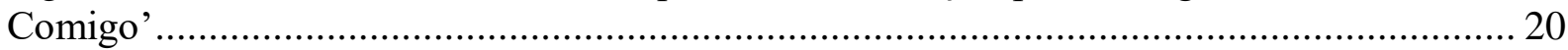

Figura 4 - O dono da mercearia separado pelo balcão de vendas em 'Conta Comigo' .......... 20 Figura 5 - A relação natural da protagonista com os meninos do bairro em 'Meu

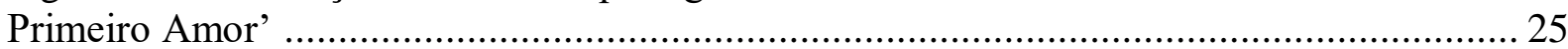

Figura 6 - O momento onde outras garotas da mesma idade que a protagonista a confrontam em 'Meu Primeiro Amor' .................................................................................... 25

Figura 7 - As aproximações da morte no amadurecimento de Vada em 'Meu Primeiro

Amor' I

Figura 8 - As aproximações da morte no amadurecimento de Vada em 'Meu Primeiro

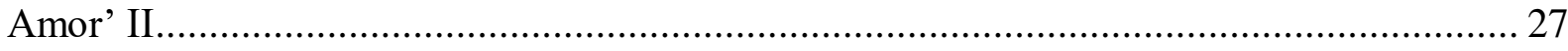

Figura 9 - As aproximações da morte no amadurecimento de Vada em 'Meu Primeiro

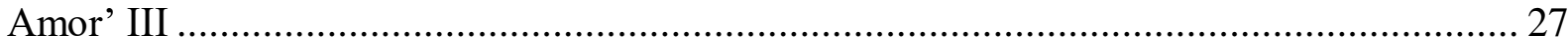

Figura 10 - O sepultamento como brincadeira cria um universo particular para as

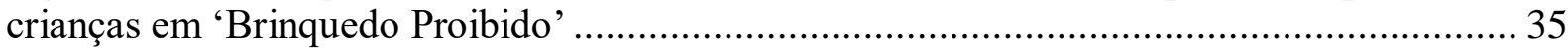

Figura 11 - A dualidade visual entre Eli e Oskar I em 'Deixa Ela Entrar' ........................... 40

Figura 12 - A dualidade visual entre Eli e Oskar II em 'Deixa Ela Entrar' ........................... 40

Figura 13 - Oskar observa sua mãe através do reflexo de um espelho em 'Deixa Ela

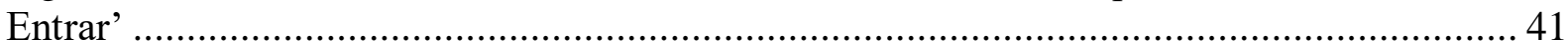

Figura 14 - Edmund rejeitado pelo mundo das crianças em 'Alemanha, Ano Zero' .............. 51

Figura 15 - Um lugar de igualdade em 'O Porco Espinho' .............................................. 54

Figura 16 - As fantasias de morte de Paloma I ............................................................ 56

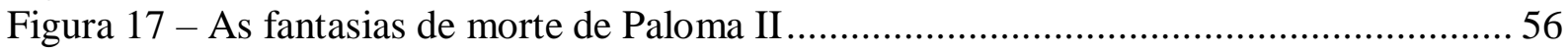

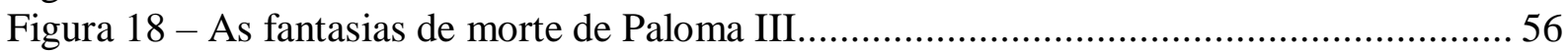

Figura 19 - Peixe como simbolismo de renascimento I ................................................. 57

Figura 20 - Peixe como simbolismo de renascimento II .............................................. 57 


\section{SUMÁRIO}

INTRODUÇÃO …............................................................................................ 13

CAPÍTULO 1: O FIM DA INOCÊNCIA ................................................................18

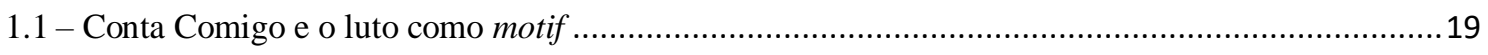

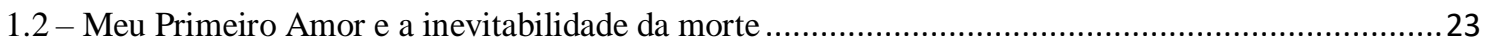

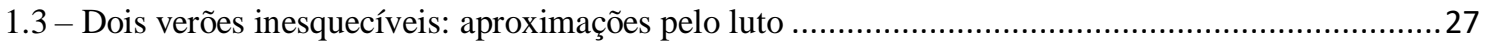

\section{CAPÍTULO 2: A CRUELDADE INFANTIL NA ASSIMILAÇÃO DA}

VIOLÊNCIA ..................................................................................................30

2.1 - Brinquedo Proibido e o sepultamento como brincadeira .............................................................. 311

2.2 - Deixa Ela Entrar e a brutalidade da solidão ..............................................................................

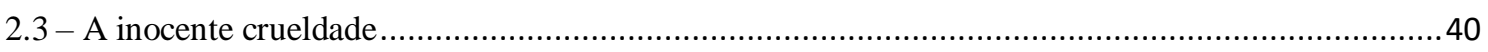

CAPÍTULO 3: O SUICÍDIO COMO ANTI-NARRATIVA INICIÁTICA..............42

3.1 - Alemanha, Ano Zero e o suicídio como escape ............................................................................. 44

3.2 - O Porco Espinho e a discreta tristeza da burguesia .................................................................. 49

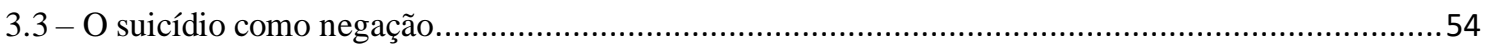

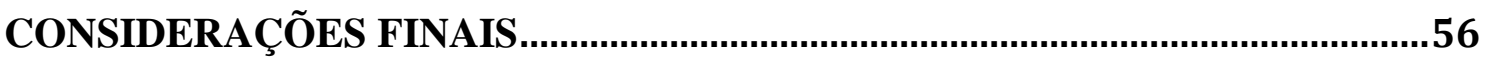

REFERÊNCIAS .............................................................................................59

FILMOGRAFIA ….......................................................................................................62 


\section{INTRODUÇÃO}

Durante a minha trajetória cinéfila, sempre possuí um grupo de filmes favoritos. Nunca havia encontrado um termo em português para nomeá-los. Por conta disso, sempre encontrei certa dificuldade em escrever e conversar sobre essas obras. Por mais que algumas delas fossem muitas vezes enquadradas em gêneros já consagrados, continuava a pensar que - embora, à primeira vista, elas aparentassem ser bastante díspares - existia algo que as conectava; algo que as aproximava mais do que as separava. Durante a minha formação, deparei-me com o vocábulo criado para definir essa série de narrativas: coming of age (narrativas de amadurecimento, em tradução livre).

Gostaria de elucidar que, por mais que conheça a conceituação de gêneros cinematográficos tanto de Rick Altman (1999) quando a de Raphaëlle Moine (2008), eu utilizarei no decorrer da minha escrita o termo "gênero" apenas como um sinônimo de categorização; agrupamento. Faço isso na tentativa de não restringir a discussão apenas à indicação das narrativas de amadurecimento como um gênero cinematográfico, mas, sim, levantar o maior número possível de apontamentos ao me debruçar sobre as características presentes em todas as obras analisadas por um viés mais antropológico

- por mais que também realize algumas rápidas observações em relação as suas estruturas narrativas e aspectos técnicos.

As narrativas de amadurecimento consistem em um gênero de produções em que seus protagonistas passam por momentos de difícil transição em sua vida - seja da infância para a pré-adolescência, seja da adolescência para a vida adulta (a 'chegada da idade' que a expressão original se refere). No ambiente acadêmico, ainda contamos com um número pequeno de estudos relacionados a essas obras, mesmo que o termo em inglês seja constantemente utilizado em críticas cinematográficas (inclusive, no Brasil) ou para classificação de obras no ambiente virtual. Grande parte do conteúdo produzido nesses estudos são compêndios de ensaios sobre algum aspecto observado em um conjunto específico de filmes; passando rapidamente pelo macro (gênero de obras) para o micro (obra abordada). Essa carência de material se agrava consideravelmente quando pesquisamos por textos em língua portuguesa. Por esse ser um objeto de estudo ainda 
em fase inicial no campo do cinema, pouco se possui de consenso sobre suas características.

Um ponto sobre essas obras, contudo, costuma ser de fácil percepção: os protagonistas das narrativas de amadurecimento, usualmente, são homens prestes a entrar na adolescência. Essa recorrência pode ser produto das reminiscências observadas nessas produções de um tipo específico de literatura: o Bildungsroman (romance de formação) - tendo seu marco inicial fixado no lançamento de Os Anos de Aprendizado de Wilhelm Meister (1795-1796) escrito por Johann Wolfgang von Goethe. As obras desse gênero literário possuem um estilo de protagonismo considerado clássico. Como afirma Wilma Patricia Maas (2000, p. 22),

[...] cristaliza-se o reconhecimento público de um gênero literário voltado para a representação do próprio ideário burguês, gênero esse que o século XIX irá conhecer como a grande forma do romance realista. Desde suas origens, o romance realista mostra-se como uma forma capaz de retratar o "homem comum", mediano. Não se representam mais seres de capacidade, força e coragem extraordinárias, mas sim o jovem que se inaugura perante a vida, que busca uma profissão, o auto-aperfeiçoamento e seu lugar no mundo. Em vez de Ulisses; o burguês.

No cinema, esse ideário burguês do jovem protagonista vivenciando suas primeiras experiências em direção ao amadurecimento somente é contraposto de forma mais perceptível, através de um número maior de obras, na contemporaneidade. A principal consequência desse fato, caso analisemos a trajetória do gênero, é a marginalização de um vasto número de personagens principais que se diferenciem do padrão, ou seja, do homem branco heterossexual, assim como as produções que protagonizam.

Para Hardcastle, Morosini e Tarte (2009, p. 3), outra aproximação entre o gênero literário e o de cinema seria que

Tanto no Bildungsroman quanto em muitos dos filmes [...], os conflitos inerentes ao amadurecimento - entre a convenção social e os desejos individuais, por exemplo levam à perda ou ao amadurecimento que esses filmes exploram.

As diferenças começam a surgir ao nos debruçarmos de maneira mais próxima e atenta sobre as narrativas. "No Bildungsroman tradicional, [as narrativas] são circulares ao invés de lineares em seu desenvolvimento" (ibid., p. 8), coisa que se prova diametralmente oposta nas narrativas de amadurecimento cinematográficas onde a transformação do protagonista ao final se prova bastante presente. 
Ao iniciar minha investigação sobre essas narrativas, percebi a recorrência de quatro grandes temáticas nos filmes: encontro da sexualidade; formação de relacionamentos significativos; amadurecimento após uma viagem; e a confrontação com os desafios da realidade social. Na primeira temática, enquadram-se majoritariamente os filmes adolescentes com temáticas que envolvam a perda da virgindade - Porky's - A Casa do Amor e do Riso (1981) de Bob Clark, e American Pie - A Primeira Vez é Inesquecível (1999) de Chris Weitz e Paul Weitz —, mas também se enquadram dramas com temática queer que possuam protagonistas infantis - Minha Vida em Cor-de-Rosa (1997) de Alain Berliner e Tomboy (2011) de Céline Sciamma. $\mathrm{Na}$ segunda temática, o caminho para amadurecimento do protagonista está ligado diretamente com sua incapacidade de criar laços com os outros. Pertencem a ela, obras como Clube dos Cinco (1985) de John Hughes e As Vantagens de Ser Invisível (2012) de Stephen Chbosky. O amadurecimento após uma viagem é auto-explicativo e dele fazem parte obras como Quase famosos (2000) de Cameron Crowe e E Sua Mãe Também (2001) de Alfonso Cuarón. Já na última temática, enquadram-se filmes com teor mais realista e com recorte de classe, onde a própria noção de infância ou adolescência é colocada em cheque como em Vidas Sem Rumo (1983) de Francis Ford Coppola e Como Nascem os Anjos (1996) de Murilo Salles.

Como se pode distinguir, em decorrência das poucas características necessárias para as obras serem classificadas como narrativas de amadurecimento, a classificação funciona como um termo guarda-chuva que, de maneira geral, engloba um grande número de filmes com temáticas bastante diversas. Poderiam ser incluídos nessa mesma categoria obras de caráter dispares como o clássico francês Os Incompreendidos (1959) de François Truffaut, a dramédia independente Pequena Miss Sunshine (2006) de Valerie Faris e Jonathan Dayton e a comédia estadunidense Superbad - É Hoje (2007) de Greg Mottola. À vista disso, optei por fazer um recorte dentro dessa classificação a partir do termo cunhado pelo pesquisador José de Souza Miguel Lopes (2008) em sua análise do cinema sobre a infância: narrativas iniciáticas.

Um processo iniciático de acordo com o autor

baseia-se numa relação exterior/interior, quer se trate do percurso de um personagem que entra no mundo dos homens (como se a criança não fizesse inteiramente parte dele ou nele devesse conquistar o seu lugar), quer se trate da descoberta de uma outra vertente, que seria um caminho iniciático direcionado para um melhor conhecimento de si, possibilitando encontrar uma entrada para o auto-conhecimento. (LOPES, 2008, p. 26) 
Por mais que o pesquisador compreenda em sua pesquisa que as narrativas iniciáticas pertençam a uma das vertentes possíveis dentre os filmes sobre a infância, utilizarei o termo aqui pensando como um recorte de maior precisão dentro do enorme escopo de obras classificadas como narrativas de amadurecimento. Assim, tal qual o pesquisador, estarei considerando narrativas iniciáticas como aquelas em que seus infantes protagonistas experimentam um rito de passagem em direção ao amadurecimento. A escolha por uma faixa de idade específica que representasse a infância somente foi possível após uma longa pesquisa. A dificuldade em encontrar uma definição acurada para esse período de vida é apontada por Ana Maria Monte Coelho Frota (2007, p. 147)

\begin{abstract}
Os dicionários da língua portuguesa registram a palavra infância como o período de crescimento que vai do nascimento até o ingresso na puberdade, por volta dos doze anos de idade. Segundo a Convenção sobre os Direitos da Criança, aprovada pela Assembléia Geral das Nações Unidas, em novembro de 1989, "criança são todas as pessoas menores de dezoito anos de idade". Já para o Estatuto da Criança e do Adolescente (1990), criança é considerada a pessoa até os doze anos incompletos, enquanto entre os doze e dezoito anos, idade da maioridade civil, encontra-se a adolescência.
\end{abstract}

Optei por selecionar obras com protagonistas de ambos os sexos e com idades que variassem entre os 5 e os 12 anos de idade; onde a passagem da infância para a préadolescência é mais evidenciada. Além disso, prezei por uma ampla variedade geográfica e de períodos históricos nas escolhas dos filmes para que, com isso, obtivesse uma pluralidade maior sobre o que seriam as características formadoras das narrativas iniciáticas, assim como os contrastes que resultassem dessas diferenças.

A decisão por analisar a morte como "rito de passagem" decorre de sua grande influência tanto nas narrativas, quanto nos protagonistas infantis. Ao contrário de outros temas presentes no gênero, a morte obriga um amadurecimento imediato da criança em decorrência da mudança de visão, estrutura e realidade que provoca. Diferentemente de outros acontecimentos, a morte é irreversível. Demonstra para o protagonista o princípio de finidade - tanto de sua existência quanto a de seus parentes e amigos. Em cada obra analisada, o fim da vida opera de uma forma distinta e, com isso, obtêm uma resposta única durante a trajetória dos personagens principais.

A morte é para o ser o momento único por excelência. É em relação a ela que se define retroativamente o tempo qualitativo da vida. Ela demarca a fronteira entre a duração consciente e o tempo objetivo das coisas. A morte não é senão um instante depois do outro, mas o último (BAZIN, 1983, p. 133). 
Para um melhor entendimento e análise, eu dividi os filmes selecionados em três categorias.

No primeiro capítulo, analiso o primeiro contato com a morte durante a infância através dos filmes Conta Comigo (1986) de Rob Reiner e Meu Primeiro Amor (1991) de Howard Zieff. As duas histórias possuem muitos detalhes contrários: o clássico da década de 1980, por exemplo, é protagonizado exclusivamente por garotos; já o romance infantil da década de 1990 possui uma menina como sua personagem principal. Contudo, é a superação do luto decorrente de um encontro presencial com a morte que permite que seus protagonistas amadureçam.

No segundo capítulo, investigo a crueldade infantil e a assimilação da violência como caráter de amadurecimento presente nas obras Brinquedo Proibido (1952) de René Clément e Deixa Ela Entrar (2008) de Tomas Alfredson. Enquanto na primeira obra, as crianças se vêem obrigados a transformar a relação que possuem com a violência e a morte para resguardar um pouco de sua inocência em tempos de guerra; na segunda, através de uma narrativa fantástica, acompanhamos uma diferente transformação relacionada à morte após o protagonista conhecer uma criatura imortal que se alimenta de sangue humano.

No terceiro capítulo, exploro o papel da morte como solução final para os protagonistas em Alemanha, Ano Zero (1948) de Roberto Rossellini e O Porco Espinho (2009) de Mona Achache. Ambas as obras são analisadas sob a óptica de uma antinarrativa iniciática - visto que, por desejarem tirar a própria vida, os protagonistas se opõem a estrutura narrativa tradicional do gênero.

Desse modo, o presente estudo possui dois objetivos principais: a análise das características que integram e aproximam as narrativas iniciáticas que, a princípio, são tão distintas; e a construção de um panorama diversificado de produções para uma reflexão mais desenvolvida das narrativas de amadurecimento em língua portuguesa. Durante a pesquisa, ainda discorro sobre as representações das crianças através dos protagonistas infantis das obras selecionadas, além dos diversos modos que a morte se apresenta nas narrativas. 


\section{CAPÍTULO 1: O fim da inocência}

Nesse capítulo, o contato prematuro com a morte será examinado através da ótica de duas obras: Conta Comigo (1986) e Meu Primeiro Amor (1991). Antes de começar a análise propriamente dita, penso ser necessária a introdução de alguns conceitos norteadores para auxiliar o estudo das narrativas de amadurecimento e, consequentemente, das narrativas iniciáticas - nosso objeto de estudo. No trabalho de Hardcastle, Morosini e Tarte (2009, p. 3) é citada a definição do antropólogo francês Arnold Van Gennep (1909) de uma cerimônia inicial, um rito de passagem, em três fases: "separação, transição e reincorporação na sociedade". Penso que esses três estágios são bastante importantes na análise das narrativas de amadurecimento. A estrutura de suas histórias perpassa necessariamente por esses três passos; seja na adaptação literária d'O Senhor das Moscas (1963) de Peter Brook até a comédia adolescente Clube dos Cinco (1985) de John Hughes.

A partir do trabalho de Van Gennep, o antropólogo britânico Victor Turner (1974) construiu a sua teoria da liminaridade, onde explorava a natureza marginal das transições. Para ele, a segunda fase — a transição — "implica um status social flutuante, um estado de identidade indefinida e potencial" (HARDCASTLE, MOROSINI e TARTE; 2009; p. 4).

As entidades liminares não se situam aqui nem lá; estão no meio e entre as posições atribuídas e ordenadas pela lei, pelos costumes, convenções e cerimonial. Seus atributos ambíguos e indeterminados exprimem-se por uma rica variedade de símbolos, naquelas várias sociedades que ritualizam as transições sociais e culturais. Assim, a liminaridade frequentemente é comparada a morte, ao estar no útero, à invisibilidade [...] (TURNER, 1974, p. 117)

Essa dificuldade em definir a si próprio como sujeito, além da aparente invisibilização de suas aflições interiores pelos indivíduos que os cercam, é outra provação a qual os protagonistas das narrativas iniciáticas necessitam transpassar. Sobrepujar esse limbo identitário, onde não se é mais considerado uma inocente criança, mas ainda não se adquiriu o status de adulto totalmente responsável por suas ações, é a verdadeira batalha. As narrativas iniciáticas são compostas por sujeitos buscando identificar o seu papel na sociedade enquanto transitam por conturbados períodos da vida — seja da infância para a pré-adolescência, seja da adolescência para a vida adulta. Eles cruzam fronteiras — às vezes físicas como as de um bairro, cidade ou país; às 
vezes somente metafóricas. "Algumas vezes o protagonista aprende alguma coisa e, em outras, ele apenas transpõe uma etapa. Trata-se da simples passagem de um a outro momento de sua vida ou da constituição mais formal de um indivíduo" (LOPES, 2008, p. 27). Por não se enquadrarem em nenhum dos grupos pré-definidos, a transgressão de convenções sociais (tais como classes sociais, gênero ou a estrutura patriarcal) pelos personagens, ocasionada de forma intencional ou não, mostra-se presente nas histórias. A conclusão desse rito de passagem oferece ao protagonista uma nova interpretação sobre si mesmo, dos indivíduos que o cercam e de seus arredores.

A multiplicidade de realidades, crianças e infâncias é um dos norteadores das narrativas iniciáticas mais consagradas. O cuidado e diferenciação dos termos como "criança" como referente ao indivíduo e "infância" referente ao tempo social e histórico em que o mesmo habita e constrói sua história (SIQUEIRA, 2011) é de suma importância para termos um olhar que foge do senso comum sobre essas obras.

As narrativas iniciáticas relembram para nós, crescidos, as dificuldades e dores presentes no ato de amadurecer. Elas dão protagonismo a indivíduos constantemente silenciados que, no passado, já foram taxados como in fans (ausentes de fala). Retratam um realismo mais brutal e sem amarras de um período comumente idealizado.

\section{1 - Conta Comigo e o luto como motif}

Motif é a ideia dominante ou recorrente em um trabalho artístico. Logo em seus minutos iniciais, ao olhar para um recorte de jornal informando que um advogado havia sido esfaqueado, uma versão adulta de Gordie (Wil Wheaton), o protagonista de Conta Comigo, nos informa em voice-over: "I was 12 going on 13 the first time I saw a dead human being"1. Na obra, o luto funciona como motif impulsionando o personagem nas duas esferas narrativas: na esfera do presente, desperta nele a vontade de escrever sobre uma aventura experienciada na juventude; e, na esfera da memória, cria uma espécie de obsessão em encontrar o cadáver desaparecido de um jovem.

\footnotetext{
1 "Eu tinha 12 anos quando vi um ser humano morto pela primeira vez".
} 
É possível identificar de forma rápida a maneira com que o filme constrói a jornada de uma narrativa iniciática. A princípio, podemos notar a composição de uma barreira física na maioria das sequências onde ocorre o encontro entre o universo infantil e o dos adultos. Isso pode ser visto desde os minutos iniciais, onde o protagonista já crescido percebe dois garotos andando de bicicleta do lado de fora de seu carro; até quando ele, dessa vez jovem, discute com o dono de um ferro-velho separado por uma grade; algo afasta esses dois universos distintos. Isso vem a acentuar a sensação de incompreensão, por parte dos mais velhos, dos problemas sofridos pelo quarteto principal de personagens.
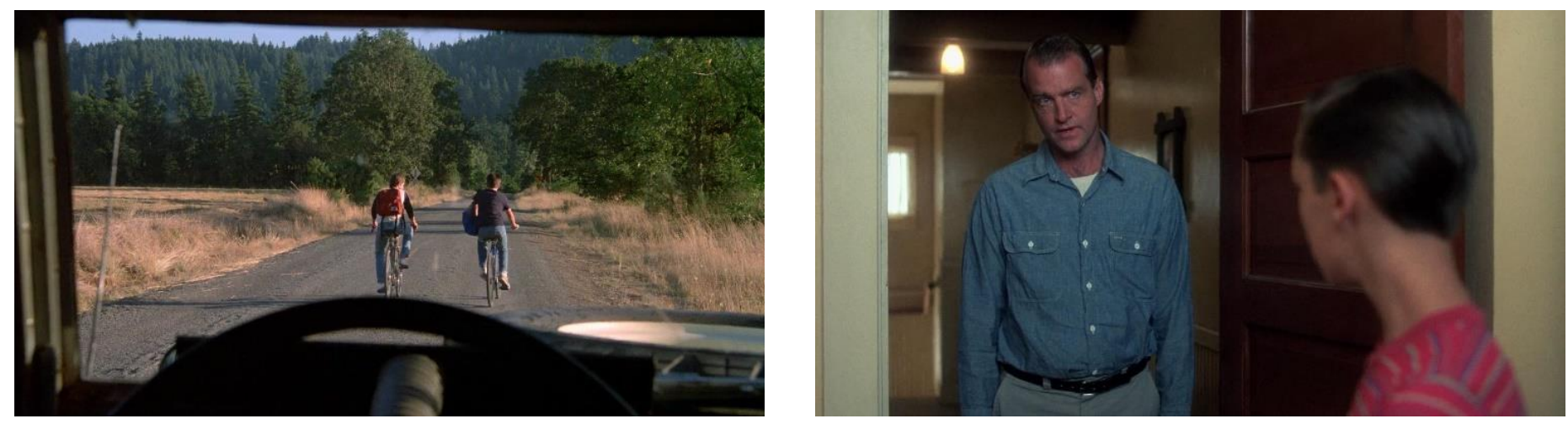

À esquerda, o protagonista adulto observa dois jovens passarem através da janela do seu carro. À direita, mais jovem, ele conversa com o próprio pai que se mantém fora do cômodo. — Frames extraídos do filme "Conta Comigo"
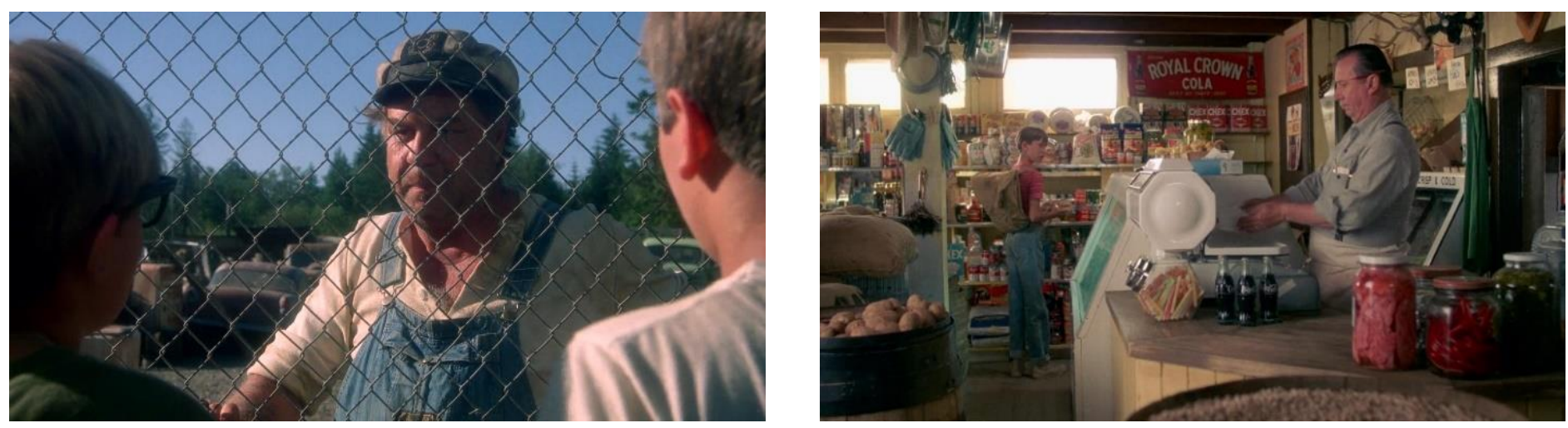

À esquerda, o dono do ferro-velho separado das crianças por uma grade. À direita, o dono da mercearia separado pelo balcão de vendas. — Frames extraídos do filme "Conta Comigo"

A comprovação de que a jornada funcionou para Gordie como um rito de passagem é demonstrada através de sua narração enquanto a relembra - possuindo um relato saudosista e amadurecido que pontua os aspectos importantes ocorridos e que o marcaram de maneira distanciada pelo tempo. 
Quando se encontrava na casa da árvore com seus amigos e recebe a notícia de que um deles conhecia a localização do cadáver de um menino desaparecido, Gordie, em um primeiro momento, compartilha junto aos outros garotos de certo interesse em relação ao assunto. Esse interesse está intrinsecamente ligado à superação do luto pela morte de seu irmão mais velho em um acidente de carro. Por conta disso, o fascínio do garoto difere da excitação de seus amigos com a ideia de encontrarem o corpo. Enquanto a morbidez melancólica de Gordie o encoraja, é a road trip proibida pelos trilhos de um trem que incentiva os outros garotos. "Ver um garoto morto não devia ser uma festa", ele fala em certo momento. Gordie, ao contrário dos outros meninos, possui uma relação diferenciada com o fim da vida, um trato quase respeitoso.

Um sentimento de inadequação é vivenciado pelo protagonista durante toda a jornada. "Você me acha estranho?", ele pergunta ao seu amigo Chris Chambers (River Phoenix). Isso é consequência da natureza marginal das transições apontada por Victor Turner, mas, também, da maneira com que os pais do garoto interagem (ou não) com ele; deixando-o de fora da tentativa do casal em superar a destituição tão precoce do primogênito em suas vidas. $\mathrm{O}$ desconforto dessa nova relação do jovem protagonista com sua família faz com que ele fantasie uma vingança contra todo o universo dos adultos. Essa vontade é observada durante a história que conta aos amigos quando estão ao redor da fogueira - protagonizada por um menino com a sua mesma idade que decide quebrar as convenções impostas através de uma vingança com toques de um ingênuo sadismo. Ao ser excluído por seus pais e não ter com quem compartilhar sua própria tristeza, Gordie guarda toda a confusão de sentimentos pra si mesmo. Seu amadurecimento ocorre quando consegue compartilhar o que sente com outra pessoa e, assim, verbalizar a culpa que o está consumindo. Primeiramente aos poucos, através de pequenas frases soltas, para, somente ao fim, dividir tudo o que o aflige com Chambers.

Chris Chambers atua na história como um catalisador de amadurecimento não só do protagonista, mas também para os outros personagens. Ele toma para si mesmo que sem intenção a função de auxiliar os amigos durante a transição da infância para a idade adulta. O personagem é o único que consegue lidar com os pensamentos suicidas de Teddy Duchamp (Corey Feldman) o salvando de ser atropelado por um trem; com a insegurança medrosa e ingênua de Vern Tessio (Jerry O'Connell); e, ao fim, com o luto de Gordie. A relação dele com Gordie parece ser a mais próxima existente entre os quatro garotos. Durante a narrativa, descobrimos a razão da personalidade diferenciada 
de Chambers: o menino havia sido obrigado a realizar o seu próprio rito de passagem de forma precoce. Ao perceber, durante a noite, que Gordie está confidenciando algo íntimo a ele ao revelar que sentia falta de seu falecido irmão, Chambers decide compartilhar a sua própria história. Ao tentar devolver o dinheiro que havia roubado do colégio e ser traído pela professora, Chambers é obrigado a amadurecer e compreender que a visão que possuía não era mais suficiente para comportar a realidade que o rodeava. O mundo dos adultos se mostrara traiçoeiro demais para que ele compreendesse com sua antiga mentalidade infantil. Essa conversa entre Chambers e Gordie consegue criar um interessante paralelo narrativo, já que antecipa a conversa que os amigos têm ao final da trama e que encerra o ciclo de amadurecimento do protagonista.

Durante a narrativa, uma crescente culpa é percebida em Gordie. Ao ser constantemente comparado pelos adultos ao seu irmão falecido de maneira a inferiorizálo, ele cria em seu interior a certeza de que deveria ter sido morto no acidente; não o outro. Em um pesadelo, vemos esse medo materializado na figura de seu pai que afirma em voz alta esse temor - "Devia ter sido você, Gordon". Durante o pouco que presenciamos da relação familiar através de flashbacks, percebe-se a predileção do casal pelo filho que seguia por um caminho mais atlético (jogador de futebol americano) do que o mais novo e sua escrita. Algo que parece se agravar com a morte abrupta do jovem durante sua carreira em ascensão.

Ao se deparar com o corpo do menino no fim de sua jornada, Gordie percebe a imutabilidade da morte — "Ele não estava desmaiado, nem dormindo. Estava morto mesmo" - e de sua ameaçadora aleatoriedade. Na conversa que tem com Chambers, o protagonista se encontra apto a confrontar tais medos e expurgar a sua culpa para que, com isso, consiga amadurecer - enfrentando a assustadora constatação de que seu irmão mais velho não havia morrido por qualquer razão específica; nem por ser pior ou melhor do que ele.

As três fases apontadas por Van Gennep são observadas durante o percurso dos quatro amigos em sua jornada. Logo em seu início, ocorre a separação dos personagens de sua família ao inventarem a existência de um acampamento e partirem em sua jornada pelas linhas do trem. A transição ocorre de maneira literal na narrativa — não somente simbólica - com o abandono do espaço urbano e adulto pelos territórios da 
floresta. A partir dessa fase inicial, os personagens interagem, na maior parte do tempo, apenas entre eles, seus pares — únicos que entendem a indefinição de identidade que estão atravessando durante o envelhecimento. A reincorporação na sociedade ocorre ao fim do filme e possui uma sequência inteira dedicada a ela. "Estivemos fora só dois dias, mas a cidade parecia diferente; menor" confidencia um Gordie adulto. Ele se refere não ao envelhecimento corporal, é claro, mas as mudanças de visão de mundo pelas quais os quatro personagens experienciaram durante a jornada. Algo havia mudado e, assim, os quatro amigos puderam voltar as suas vidas cotidianas para assumirem os papéis que pensavam serem os destinados a eles.

\section{2 - Meu Primeiro Amor e a inevitabilidade da morte}

Durante uma discussão entre dois personagens é dito que a protagonista, Vada Sultenfuss (Anna Chlumsky), está confusa sobre o real significado da morte. Essa confusão é o que define a jornada da personagem principal. Durante todo o desenrolar da trama, o amadurecimento da garota permanece intrinsecamente ligado à sua oculta culpabilização pela morte da mãe.

Logo em sua primeira sequência, Meu Primeiro Amor demonstra uma dinâmica interessante. Através de um rápido monólogo quebrando a quarta parede, Vada, uma menina de 11 anos, apresenta sua própria hipocondria através de histórias inventadas onde teria, entre outras coisas, um osso de frango preso a sua garganta. Nessa mesma sequência, descobrimos a relação distante que a personagem possui com o próprio pai que não aparenta dar atenção a ela. É durante esses interlúdios, onde a personagem se remete diretamente a câmera e aos espectadores, que Vada consegue se expressar de forma sincera e aprofunda sua psique e história pregressa.

Vada é apresentada como uma menina que possui um estilo similar aos dos outros garotos; tomboy ${ }^{2}$. Seu temperamento difícil somado a sua hipocondria, tornam o cotidiano dela solitário - exceto pela presença de seu fiel amigo, Thomas J. (Macaulay Culkin), que a acompanha durante as inúmeras visitas sem propósito ao consultório médico. Vada sempre pensa que está sofrendo da mesma enfermidade que vitimou o

\footnotetext{
${ }^{2}$ Garotas que se vestem e têm gostos parecidos com os dos garotos.
} 
cadáver recém-chegado em sua casa-funerária, onde mora junto de seu pai e da avó de sua finada mãe. Um dos elementos narrativos que impele a garota em direção ao amadurecimento é o surgimento da maquiadora Shelly Devoto (Jamie Lee Curtis). Ao chegar à vida da menina e do seu pai, a mulher assume pra si o papel de matriarca da residência.

As únicas garotas que possuem a mesma faixa de idade da protagonista surgem durante o filme para expor a inadequação de Vada em se encaixar aos grupos sociais pré-concebidos. A inadequação que a personagem principal vivencia por conta de sua incompatibilidade com o universo das garotas de seu círculo social é consequência direta de seu fascínio tanto pela morte, quanto pela literatura. A superação da dificuldade de Vada em expor seus sentimentos e desejos com outra pessoa além de Thomas J. será fundamental para que ela consiga desfazer os pré-julgamentos que possui sobre o grupo feminino e, até mesmo, consiga se tornar amiga de uma delas.
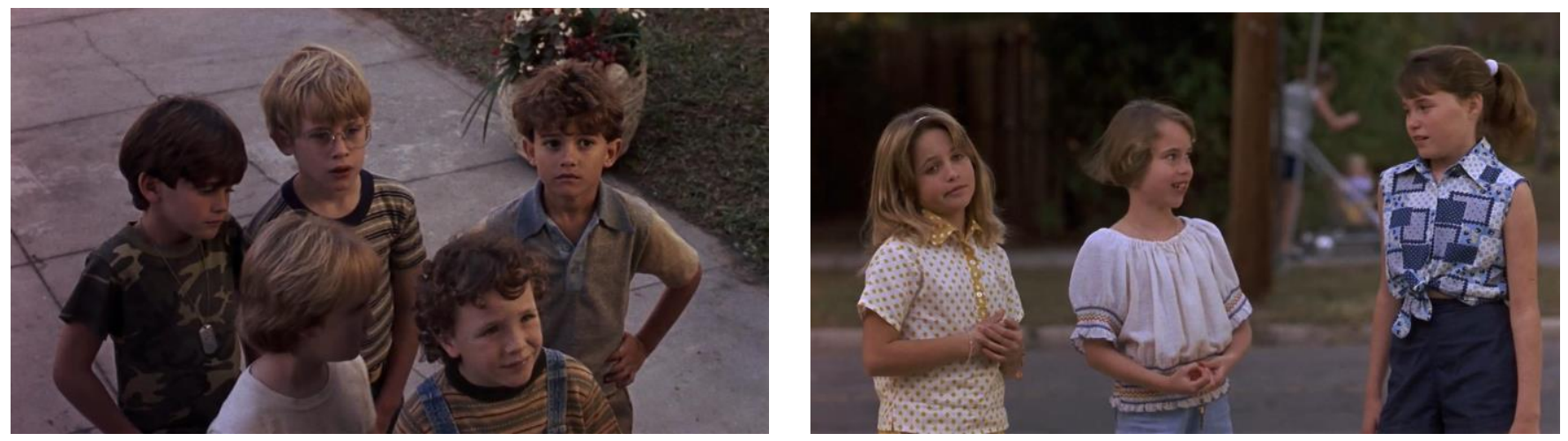

Na esquerda, podemos ver a relação natural da protagonista com os meninos de seu bairro, incluindo seu melhor amigo Thomas J. Na direita, o momento onde outras garotas da mesma idade que a protagonista a confrontam — Frames extraídos do filme "Meu Primeiro Amor".

A própria Vada é quem revela a sua mórbida dúvida interna aos espectadores: será que havia sido ela a culpada pela morte de sua mãe? A morte de sua progenitora é revelada aos poucos em diálogos que, de forma geral, não possuem a presença da protagonista. Descobrimos, por exemplo, que a mulher faleceu devido a complicações no parto, o que esclarece a razão de Vada se culpar pela perda. A partir dessas conversas entre os adultos, podemos observar que seu pai não lidou bem com a morte de sua esposa, evitando a todo custo falar diretamente sobre o assunto com a filha. Em um momento da narrativa, o tio de Vada comenta com a menina que seu irmão costumava ser bastante engraçado antes de sua esposa falecer. A garota o questiona, desacreditada. Essa conversa ilustra um dos temores que Vada precisará transpor em direção ao 
amadurecimento: ela nunca havia conhecido verdadeiramente o pai em decorrência do luto.

A morte sempre está presente no cotidiano da protagonista e em cada um dos cômodos de seu lar — uma casa-funerária - por mais que não esteja propriamente visível. Durante o filme, a morte, metafórica e fisicamente, vai se aproximando cada vez mais de Vada. Essa aproximação sutil em direção a uma confrontação direta é parte de sua trilha para o amadurecimento. Logo no início do longa-metragem, descobre-se que a protagonista nunca avistou os mortos que chegam até a sua casa-funerária; somente seus caixões. Por mais que, a primeira-vista, a personagem lide bem com o fato de ser rodeada pela morte em sua forma mais primitiva; o roteiro deixa pistas de que a menina tem uma relação mais complexa com o fim da vida em momentos como, por exemplo, onde interpela o pai sobre os caixões pequenos destinados a crianças como ela. $\mathrm{O}$ roteiro sabe se utilizar dessa dualidade presente entre corpos mortos e uma menina começando sua vida, ambos coexistindo entre si. Destaco aqui os três momentos que ilustram a jornada de amadurecimento pela qual Vada perpassa durante a história e a aproximação cada vez maior da morte.

O primeiro momento-chave ocorre quando seu pai pede para que a garota leve um maço de cigarros para ele, enquanto o mesmo embalsama um cadáver. Nesse momento, por mais que a morte esteja à espreita, a garota não possui muita ideia sobre o que de fato ela signifique. Essa sequência, ao colocar Vada conversando com o pai e o outro funcionário sem que observasse o trabalho feito pelos homens no corpo morto, ilustra essa visão prematura e infantil sobre o fim - apenas intensificada quando a menina começa a cantar e é expulsa do ambiente pelo patriarca em decorrência de sua falta de respeito não intencional.

Em um segundo momento, Vada desce sozinha de encontro à morte ao perder sua bola de basquete e, após um descuido, tranca-se junto a um cadáver; sozinha. Nesse momento, há uma aproximação por parte da garota. Por mais que o finado esteja coberto por um lençol, ela consegue delimitar sua forma e perceber a gravidade daquela situação; assim como o entendimento de Vada sobre a morte vem se aprimorando. Nesse primeiro encontro direto, a protagonista se descontrola dando dicas sobre o conflito interno que sofre. Essa confrontação acontece logo após um desentendimento 
com seu pai, construindo assim uma relação de causalidade com a errônea ideia de culpa que a protagonista possui sobre a morte de sua mãe.

O terceiro momento ocorre durante o velório do melhor amigo de Vada, Thomas J. Por mais que ela se tranque em seu quarto evitando, em um primeiro momento, lidar com a situação de forma próxima e direta; a morte do amigo inicia uma série de confrontações envolvendo desde uma paixão platônica por seu professor até, finalmente, sua culpabilização pela morte da mãe. Isso pode ser ilustrado através da máxima aproximação dela do cadáver do amigo e, simbolicamente, da morte em si. Nesse momento, ela consegue ver a imutabilidade daquele ato, a ponto de se importar com o amigo sendo enterrado sem a presença de seus óculos costumeiros.
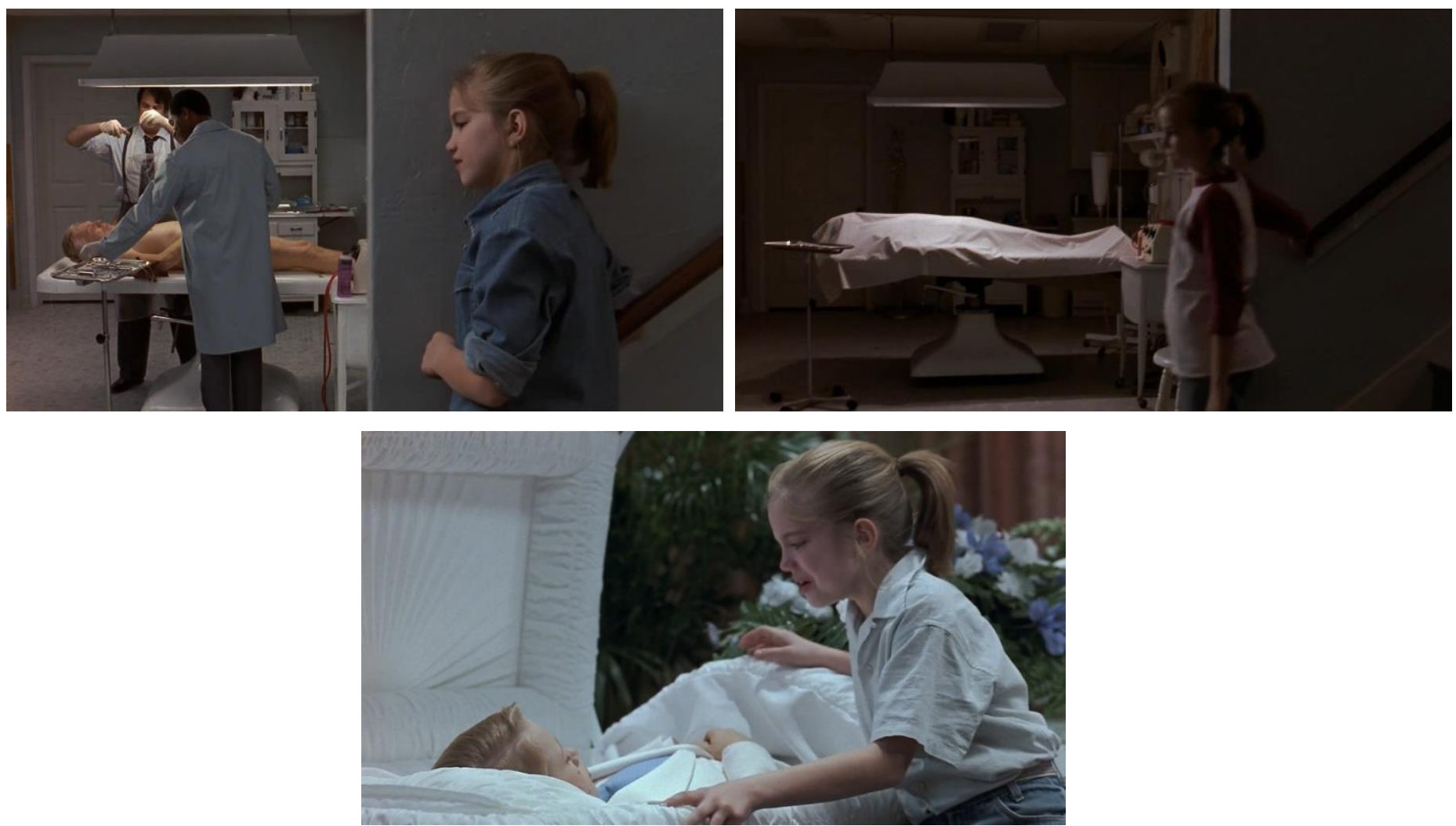

As aproximações da morte no amadurecimento de Vada — Frames extraídos do filme "Meu Primeiro Amor".

No diálogo com o pai que sintetiza o seu amadurecimento, Vada confronta finalmente o homem sobre a morte de sua mãe. Mais do que ouvir uma negativa como resposta a sua própria culpabilização, o maior desejo da garota se constitui na 
demonstração de algum sentimento por parte do patriarca. Ele atende às suas expectativas e revela que, durante todos aqueles anos, havia tentado proteger a filha da morte. A fala dúbia do patriarca funciona tanto em relação ao trabalho funerário que ele havia impedido que sua filha assistisse; quanto em relação ao seu próprio sentimento de luto pela morte da esposa que havia escondido durante anos.

A narrativa iniciática da protagonista de Meu Primeiro Amor consiste da junção entre a proximidade do primeiro vislumbre do fim da vida e da mudança de sua própria visão sobre a morte. Thomas J. explica a hipocondria da amiga em dado momento como uma resposta ao medo irracional que Vada sente dos mortos que passam por sua casafunerária. "É como o ditado", ele explica, "se não pode com eles, junte-se a eles". Esse medo sem explicação dos cadáveres e sua própria culpabilização pela morte da mãe são os obstáculos que a menina precisou atravessar para amadurecer. Esse amadurecimento fica explícito durante o diálogo final entre Vada e a mãe de Thomas J., onde a protagonista a consola dizendo que sua própria mãe cuidaria do garoto no além-vida. Em apenas um diálogo, a protagonista demonstra ter abandonado o medo que possuía dos mortos que chegavam a sua casa-funerária - visto que o seu melhor amigo havia se tornado um deles e, com isso, construído uma intimidade dela com a morte - e que havia superado a culpa pelo falecimento da mãe.

\section{3 - Dois verões inesquecíveis: aproximações pelo luto}

Além de abordarem visões semelhantes de percepções da morte, existe algo ainda mais curioso que une os dois longas-metragens estadunidenses analisados nesse capítulo: ambos se passam em décadas anteriores a de seu lançamento. Meu Primeiro Amor, lançado em 1991, tem uma narrativa que se desenrola nas férias escolares ocorrido durante a década de 1970. Conta Comigo, lançado em 1986, tem um narradorprotagonista que nos transporta para suas memórias do fim da década de 1950. Ambos os filmes carregam, em si, certo grau de reminiscência - ainda mais evidente em decorrência das décadas pregressas nas quais se ambientam. Por mais que o cerne da trama se concentre na jornada pessoal de seus protagonistas, ambas narrativas são influenciadas pelos contextos históricos e geográficos pregressos dos EUA. Criando, dessa forma, um retrato de uma época e de suas imagens e sons consagrados como o 
rock-and-roll, a moda, as tendências específicas daquele período, etc. Decorrente disso, as duas obras podem ser analisadas como narrativas de amadurecimento das próprias localidades onde ocorrem.

A morte surge no cotidiano de ambos os protagonistas de maneira sutil e pregressa a narrativa assistida. Tanto Vada de Meu Primeiro Amor, quanto Gordie de Conta Comigo já iniciam suas próprias narrativas enfrentando o luto pela morte de pessoas importantes e próximas. Por mais que não tenham, à primeira vista, encarado diretamente a morte, ambos se culpabilizam: Vada pelo falecimento de sua mãe em decorrência de problemas em seu nascimento; e Gordie por não ter perdido a vida no lugar de seu irmão mais velho. Gordie e Vada se utilizam de sua imaginação para superarem a fase difícil na qual se encontram: o menino através de suas histórias, a garota através de seus autodiagnósticos inventados. A morte surge aqui não somente como a perda de uma pessoa amada, mas como um lembrete, uma ameaça de sua aproximação inevitável. Em Vada, isso se concretiza através de sua hipocondria. Em Gordie, o luto se mostra através de seus pesadelos e de sua apatia com relação a sua própria vida e escolhas para o futuro. O luto é aqui compreendido tal qual a concepção de Bromberg (1998, p. 11) como "um conjunto de reações a uma perda significativa". As vulnerabilidades individuais de cada um são expostas em decorrência desse primeiro contato com o fim da vida.

Por conta da falta de diálogo e da repressão de emoções, os pais se tornam o principal ampliador do luto nos personagens principais de ambas as obras. Nessas narrativas, a falta de comunicação entre adultos e crianças tem início desde o nascimento, como é o caso de Vada que não imaginava a existência de uma versão engraçada do próprio pai no passado; ou transforma todos os membros de uma família em indivíduos monossilábicos como é o caso do Gordie e seus pais.

Ao moldar a trajetória dos protagonistas com sua aparição direta ainda na infância, a morte os compele a enfrentar as três fases descritas por Van Gennep. A separação, primeira e mais perceptível delas, ocorre pela incompreensão dos aspectos do luto e o entendimento de que ninguém poderá entendê-las. De acordo com Aberastury (1984, p. 135), "a criança não conhece muito bem como é o processo da morte, mas experimenta a ausência que ela vive como abandono". Já a segunda fase, transição, ocorre de duas maneiras distintas nas obras. Em Meu Primeiro Amor ocorre 
através do contato de Vada com a figura materna de Shelly e da abertura emocional tardia cedida por seu pai. Já em Conta Comigo a transição de Gordie sucede através das interações realizadas entre seus pares durante a jornada que vivenciam. A reincorporação na sociedade, fase final, ocorre com a finalização do luto e com a percepção do contato com as pessoas perdidas através de memórias e lembranças. Essa conexão através de memórias se manifesta em Conta Comigo através dos flashbacks que Gordie possui onde relembra de seu irmão — além da recordação da própria narrativa após a morte de Chris Chambers no presente —; e, em Meu Primeiro Amor, manifesta-se através do poema declamado por Vada ao final: "Weeping willow, stop your tears. There is something to calm you fears. You think death has ripped you forever apart. But I know he'll always be in your heart" ${ }^{3}$.

\footnotetext{
3 "Salgueiro chorão, pare de chorar. Pois há algo que pode te consolar. Você acha que a morte separou vocês para sempre. Mas eu sei que ele sempre estará em seu coração".
} 


\section{CAPÍTULO 2: A crueldade infantil na assimilação da violência}

Nesse capítulo a crueldade infantil é analisada como uma ferramenta para a trajetória dos protagonistas durante a assimilação da violência extrema que os cerca. Por conta disso, serão examinadas obras onde tanto a morte quanto a violência exacerbam. Nelas, seus protagonistas são obrigados a lidar, ainda durante a infância, com problemas extremos envolvendo a morte e que terminam por transfigurar a sua personalidade aproximando por vezes algumas de suas ações à crueldade. A morte nessas obras não cumpre somente a função de despertar o amadurecimento, mas de modificar irreversivelmente o caráter psicológico dos seus personagens principais.

No seu estudo sobre a figura da crueldade infantil na literatura e em diferentes culturas, Monica Flegel e Christopher Parkes (2018) expõem a oposição existente entre os escritores religiosos e os românticos do século XIX sobre o período da infância. Enquanto os autores religiosos, por conta do seu embasamento bíblico, compreendiam a criança como "nascidas com o pecado original e necessitadas de rígida disciplina para serem mantidas no caminho da salvação" (ibid., p. 4); a tradição romântica a concebia como um ser puro e bondoso que "só poderia corromper tal perfeição ao colonizar a inocente criança para participar do mundo adulto" (ibid., p. 3). A concepção estabelecida, preto no branco, sobre a índole dos jovens protagonistas que povoavam a literatura do século XIX se acinzentou durante o tempo.

No século após a fronteira gótica de Twain, a figura da criança malvada firmou a sua principal morada nos filmes de terror dos EUA. [...] O dever da família de proteger a criança entra em conflito direto com a absoluta necessidade de se livrar do ser monstruoso. (ibid., p. 6)

O papel da família citado pelos autores, talvez, seja a principal distinção entre os filmes comuns com personagens infantis malvados e as narrativas iniciáticas com protagonistas cruéis. Em obras como Tara Maldita (1956) de Mervyn LeRoy, A Inocente Face do Terror (1972) de Robert Mulligan, O Exorcista (1973) de William Friedkin e A Profecia (1976) de Richard Donner, a crueldade serve ao propósito de “testar nossa crença na reabilitação" (ibid., p. 6) do personagem infantil. Além disso, os familiares ou adultos em geral possuem uma grande importância no desenrolar da trama - podendo tomar para si o papel de protagonistas; como é o caso do jovem padre 
Damien Karras (Jason Miller) que possui, através do conflito que enfrenta com sua fé, o componente principal do clássico de exorcismo da década de 1970.

Por outro lado, as narrativas iniciáticas pretendem conceder total protagonismo para seus personagens infantis. Em função disso, elas distinguem de maneira bastante precisa o universo habitado pelos adultos e o pertencente às crianças. A relação da criança com seus pais, por exemplo, é mostrada de maneira bastante distanciada; o que pode ou não vir a se tornar uma das dificuldades a serem perpassadas durante a trama. Nos filmes onde a crueldade e a violência se apresentam como fatores determinantes nas ações dos seus protagonistas, como os vistos nesse capítulo, os adultos recebem uma maior participação — sem, com isso, suprimir o protagonismo da criança. Os responsáveis atuam nessas narrativas como uma régua moral para mostrar a gravidade das ações cometidas pelos jovens.

No segundo filme analisado, o sueco Deixa Ela Entrar (2008) de Tomas Alfredson, será estudada a subversão feita pela narrativa durante a sua construção da figura da criança cruel através do menino Oskar e da vampira Eli. A narrativa especula sobre a gênese dos atos violentos de seus protagonistas - tanto a criatura que se alimenta de sangue humano, quanto Oskar e sua aterradora submissão aos valentões de sua sala de aula. Já na primeira obra investigada, a francesa Brinquedo Proibido (1952) de René Clément, deparamo-nos com uma elaboração mais realística da crueldade durante a infância. A figura da pequena Paulette, menina loira e ingênua, é balanceada pelo interiorano e sábio menino Michel. No decorrer da narrativa, apenas um desses personagens é castigado pelos atos encarados como cruéis. Assim como apontado, "O que se torna importante, então, [...] é a maneira pela qual a violência e a agressão são toleradas em algumas crianças, mas não em outras" (ibid., p. 6) e "[...] não é fácil [a sociedade] destruir uma garotinha loira que está muito mais próxima do centro da cultura dominante" (ibid., p. 6).

\section{1 - Brinquedo Proibido e o sepultamento como brincadeira}

Como apontado em seus créditos iniciais através do folhear de páginas de um livro de histórias, "Brinquedo Proibido" possui um tom fabular - mas não 
convencional. Logo em seus primeiros instantes, os espectadores são atingidos pela dura realidade do período em que a história se passa: Batalha da França, 1940. Paulette (Brigitte Fossey), garotinha de cinco anos, foge com sua família de um ataque aéreo alemão. Em decorrência de uma investida dos nazistas, os pais da menina são mortos, assim como o cachorrinho que os acompanhava. Diante disso, a protagonista abandona a caravana de fuga e passa a seguir o curso do rio pelas suas margens. Seu objetivo é recuperar o cadáver de seu animal de estimação lançado nas águas. Após conseguir recuperar o corpo do filhote e se encontrar desamparada em uma floresta intimidadora, Paulette é socorrida por Michel (Georges Poujouly) que a leva até a sua casa e, assim, até a sua família.

A partir desse encontro entre as duas crianças, acompanhamos as situações pelas quais a protagonista passa na tentativa de internalizar as tragédias que presenciou. Em um primeiro momento, Paulette parece estar enfrentando seu processo de luto de forma estranhamente calma. Ao ser questionada por Michel sobre a localização de seus pais, resume-se a um choroso: "está morta" e "está morto". A personagem se resigna de forma rápida a morte de seu cachorro, mesmo tendo perseguido seu corpo sem vida pelo rio, abandonando o seu pequeno cadáver frente à promessa de um novo animalzinho.

Após ser resgatada da floresta — cenário corriqueiro de conto de fadas —, a protagonista é transportada para um ambiente interiorano onde a guerra nunca se é vista diretamente, mas somente comentada. Paulette se vê em meio a novas noções sobre os horrores da guerra, a morte e a religião. Como perceberemos durante o avançar da trama, ela enfrenta sentimentos internos conflitantes - em partes, advindos de sua ingenuidade e desconhecimento de certas conceituações.

Como destaca o teórico e crítico de cinema André Bazin (2014, p. 134) em sua análise do filme,

\footnotetext{
"uma rajada de metralhadora mata os pais de Paulette, assim como seu cachorrinho, mas como nunca havia experimentado a morte antes, o cão morto domina uma parte muito maior de sua tristeza do que a destinada aos corpos dos pais, deixados para trás na estrada".
}

Em "Brinquedo Proibido", tal como apontado por Helene Berman (2000, p. 119) em seu artigo sobre as narrativas de crianças que testemunharam guerras, "a guerra representa uma erosão dos pressupostos básicos sobre a ordem dada como certa”. No primeiro vislumbre que temos da menina e seus pais, a família aparenta, com suas 
inúmeras malas, pertencer a uma alta classe e ter dificuldade em desapegar de bens materiais - a tentativa frustrada de salvar o carro pode ser um indício. A obra traça a dualidade existente entre Paulette simbolizando essa classe abastada e sua preocupação com a materialidade de suas posses, e Michel com seu altruísmo interiorano e seu apego, ao menos durante o início, com as tradições passadas a ele - como o catolicismo.

O conflito do filme é majoritariamente subjetivo. A tragédia ocorre logo em seus minutos iniciais. $\mathrm{O}$ que se sucede é o caminho que a protagonista percorre para assimilar a violência presenciada. Essa trajetória é desencadeada após a descoberta de Paulette do anseio dos adultos em enterrar cadáveres em caixões. Mesmo sendo um antigo morador do lar e possuindo conhecimento de sua cultura, Michel não sabe responder aos questionamentos feitos pela menina envolvendo os enterros. Pela falta de explicações, Paulette conclui que o motivador dessa preocupação seria o fato dos cadáveres pegarem ou não chuva - o que a incita, no dia seguinte, a enterrar o corpo abandonado de seu cãozinho.

O luto é apontado por Arnold Van Gennep (1977, p. 129) como "um estado de margem para os sobreviventes, no qual entram mediante ritos de separação e do qual saem por ritos de reintegração na sociedade geral". Pelo desconhecimento de concepções como a morte e o rito funerário pela protagonista; se faz necessário que o menino Michel a conduza pelo "rito de separação" mencionado por Van Gennep. Para isso, eles iniciam em conjunto um cemitério de animais - o brinquedo proibido do título. O garoto também ensina a Paulette dogmas religiosos como o significado da cruz e da oração. Michel apresenta os "procedimentos materiais de separação" como "fosso, caixão, cemitério, grade, [...] os quais são construídos ou utilizados ritualmente" (ibid., p. 141).

A idealização do cemitério de animais ocupa um espaço cada vez maior dentro da relação entre Michel e Paulette conforme a história avança. São durante as conversas sobre o lugar que a protagonista externaliza, ainda que de maneira indireta, os seus temores relacionados à perda precoce dos pais. $\mathrm{O}$ projeto se torna um refúgio para as crianças contra os problemas distantes do universo adulto que invadem as suas vivências - como a rivalidade existente entre as famílias vizinhas e os perigos da guerra. 


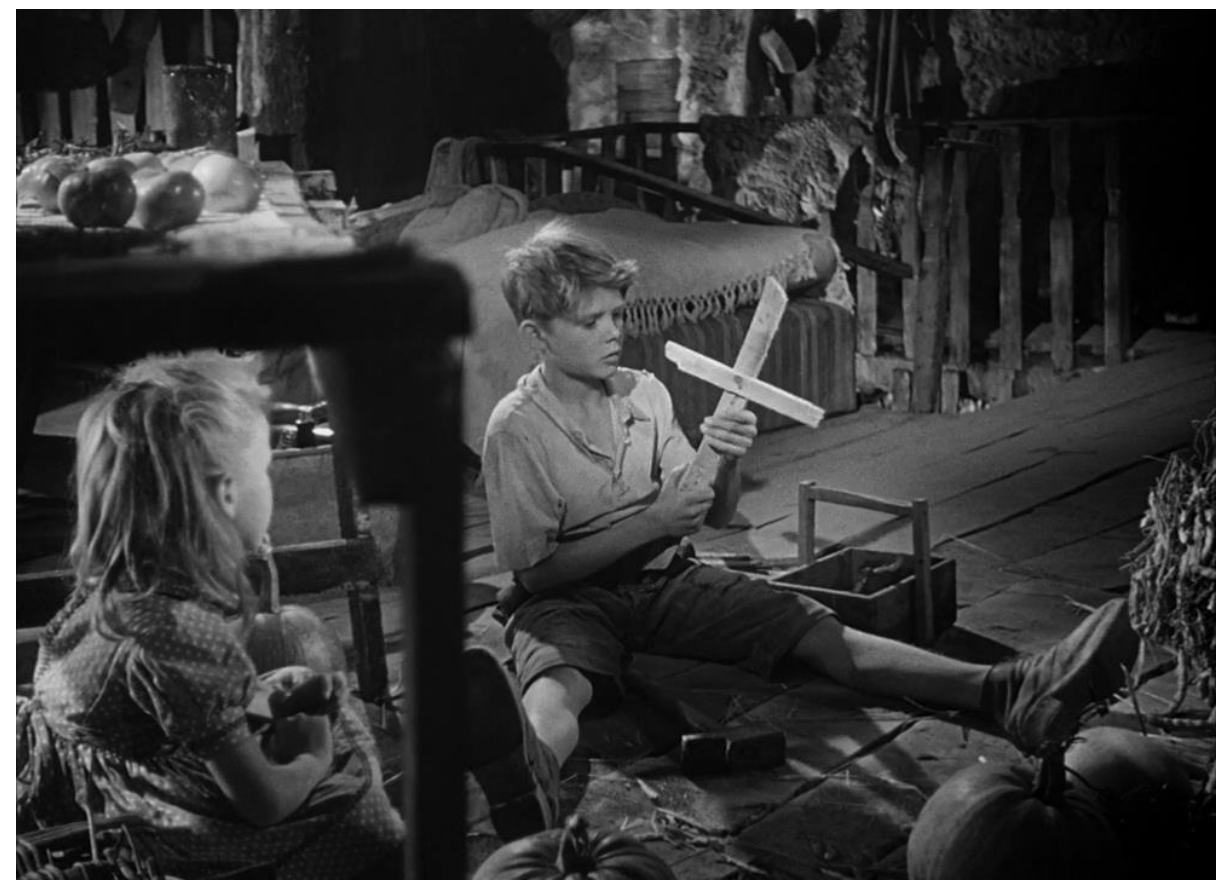

O sepultamento como brincadeira cria um universo particular para as crianças — Frame extraído do filme "Brinquedo Proibido".

A figura da cruz parece atrair a atenção de Paulette. Pode-se entender essa fixação da menina ao desassociar o caráter religioso do objeto, assim como a personagem faz. A cruz é o único pedaço aparente das sepulturas que ela constrói com Michel; todo o resto é enterrado junto aos corpos. O desejo que a menina sente de conseguir cruzes cada vez mais elaboradas dialoga diretamente com sua necessidade pela materialidade de suas posses; algo que consiga compreender, ao menos por sua beleza estética. Por conta disso, cada vez que Michel consegue satisfazer a vontade da protagonista por uma cruz mais aperfeiçoada, apenas gera uma nova e mais dificultosa. As crianças, que inicialmente construíam suas próprias cruzes, passam a furtá-las: primeiramente da carroça funerária, depois da Igreja — tentativa falha —, até o máximo sacrilégio com o roubo das cruzes do cemitério, o encarado como cemitério verdadeiro pelos personagens adultos.

O filme atinge seu clímax quando o âmbito dos mais velhos colide com a brincadeira dos pequenos personagens. Como apontado por Bazin (2014, p. 134), "são os adultos, para quem a lógica da brincadeira de Michel e Paulette é estranha, que projetam nela um significado moral’. As crianças são indiretamente responsáveis pelo sofrimento dos outros personagens que as cercam - impulsionando a rivalidade entre as famílias através do roubo das cruzes, por exemplo. 
Por compartilhar um caráter fabular decorrente do ponto de vista fantasioso de seus personagens - principalmente, pela ótica ingênua de Paulette em relação à morte —, pode-se fazer um paralelo do filme com alguns dos contos de fadas escritos pelo Oscar Wilde a cerca da crueldade infantil com o propósito de um melhor entendimento dos personagens principais retratados em "Brinquedo Proibido". Monica Flegel (2018, p. 41) destaca que

Os jovens personagens de Wilde repetidamente causam sofrimento a outros, mas muitas vezes sua crueldade não é algo que possa ser facilmente identificado como deliberada ao contrário, é um subproduto de sua atração pela beleza e sua imersão em uma sociedade que também a valoriza.

Assim como os protagonistas infantis de Wilde, Paulette acarreta acidentalmente situações ruins para os personagens mais velhos em consequência de sua atração pela beleza estética; forma com que encontra de encarar o próprio luto. Semelhante as obras do escritor britânico, a ação de Paulette e Michel, compreendida como cruel pelos adultos, é "ao menos em parte, inspirada pela falta de total compreensão" (ibid., p. 49) por parte das crianças.

A moralidade, a questão monetária (preço das cruzes) e a legal (temor da polícia) que são lançadas sobre a brincadeira dos personagens são responsáveis, assim como o abrupto envio de Paulette para um orfanato, pela não superação da morte dos pais pela protagonista. Por conta disso, seguindo o pensamento de Van Gennep, a menina nunca é reintegrada na sociedade geral, mas deixada em um limbo. O plano final onde a menina procura por Michel na estação ferroviária pode ser compreendido como sua rejeição ao seu novo destino, assim como uma nova perda - transportando novamente a personagem para um lugar tão solitário quanto à floresta.

A convivência entre Michel e Paulette é responsável por modificar ambas as crianças. A protagonista é auxiliada a resolver suas questões internas ocasionadas pela violência e vê a relação entre os dois retalhada de forma repentina. Esse corte abrupto do vínculo entre os dois personagens pode ser o principal responsável por impedir Paulette de atravessar por suas próprias etapas do luto e do amadurecimento. Já Michel, ao se deparar com o desconhecimento da garota de valores básicos de sua comunidade, encontra-se ressignificando alguns dogmas e rituais; além de encontrar na figura de Paulette uma companheira para o domínio da infância onde habitava solitário no território do seu lar. 


\section{2 - Deixa Ela Entrar e a brutalidade da solidão}

A primeira visão que temos de Oskar (Kåre Hedebrant), o jovem protagonista de 12 anos, já é atrelada a violência. Empunhando uma pequena faca, o garoto ameaça um ser invisível; exigindo que sua vítima imaginária grite como um porco. Mais tarde, descobrimos que "porco" é a forma com a qual ele é chamado pelos bullies de sua escola. A aparente atitude violenta do personagem decorria de suas constantes fantasias de vingança.

Deixa Ela Entrar se utiliza do folclore concebido em torno do mito vampiresco para construir uma alegoria sobre solidão e companheirismo. O resultado é um filme que se utiliza das convenções de gêneros já estabelecidos — como o horror e o drama - originando um hibridismo que dificulta sua classificação. Como é ressaltado por Rochelle Wright (2010, p. 56), a película

simultaneamente baseia-se e afasta-se de temas e motifs comuns [...] das tradicionais obras vampirescas; combinando elementos de terror e de narrativas de amadurecimento com um realístico drama sociopsicológico para criar uma mistura única entre o inovador e o familiar.

A história se desenvolve em torno de Oskar que passa a maior parte de seu cotidiano alternando entre as paredes da escola e de seu próprio quarto. Entre suas principais dificuldades sociais está a falta de amigos, a relação distante que mantém com seus pais divorciados e as constantes humilhações que enfrenta dos outros alunos em sua sala de aula. Como consequência, Oskar imagina recorrentemente uma violenta vingança contra seus algozes. O limiar entre o seu imaginário e o real fica obscurecido após a chegada de uma nova vizinha para o apartamento ao lado. Eli (Lina Leandersson), aparentando possuir a mesma idade que Oskar, surge como uma forasteira tão solitária quanto ele.

Por mais que ambos os personagens não possuam um caráter receptivo ou acolhedor, a recém-chegada logo desperta o interesse do protagonista. A primeira tentativa de aproximação por parte de Oskar é rapidamente rejeitada pela menina que afirma que eles não poderiam ser amigos. Isso se modifica quando o protagonista presenteia Eli com um cubo-mágico. Em uma ótica direcionada aos ritos de passagem, Arnold Van Gennep percebe, ao analisar a relação entre várias tribos e sociedades, que "aceitar um presente de alguém significa ligar-se a tal pessoa" (1978, p. 44). Se 
relacionarmos esse fato com a mitologia vampiresca, entretanto, descobriremos, além disso, que uma das características dessas criaturas é que são "fascinadas por quebracabeças" (WRIGHT, 2010, p. 58). O presente de Oskar ainda se conecta a outra característica dos vampiros: a iniciativa partindo do outro, do humano - o convite para entrar nas residências, por exemplo. Durante a obra, Eli tenta retribuir o ato de variadas maneiras: ao oferecer uma pequena peça oval que se vendida, segundo ela, "poderia comprar uma usina nuclear"; ou oferecendo dinheiro a Oskar — ambas tentativas negadas veementemente pelo garoto.

Decorrendo entre 1981-82, o pano de fundo do filme é Blackeberg, subúrbio de Estocolmo onde o roteirista viveu por toda sua infância. Durante a projeção, acompanhamos alguns moradores desse subúrbio que tem suas vidas alteradas pelas recentes notícias: o surgimento de corpos drenados de sangue e o desaparecimento de um homem. Essa pluralidade de pontos de vistas é necessária para que possamos conhecer, logo de início, o caráter violento que cerca a menina Eli - como quando a vemos atacar violentamente um homem durante a noite.

O longa-metragem segue em paralelo a rotina de Oskar com suas recorrentes humilhações sofridas na escola e o desenvolvimento da amizade entre o protagonista e Eli. Enquanto presenciamos as agressões recebidas pelo garoto gradualmente aumentando de intensidade e se tornando mais violentas, Oskar é influenciado por sua vizinha, de forma cada vez mais efetiva, a revidar e dar materialidade a sua vingança imaginária.

Após ter posto em prática sua retaliação ao golpear de forma inesperada um de seus agressores, Oskar decide selar de vez seu pacto de sangue com Eli e, simbolicamente, com a sua própria violência interior. Contudo, além de sua vontade ser negada, é nesse momento que o menino descobre o caráter sobrenatural que havia estado oculto: ela é uma vampira. Essa nova informação, ao contrário de afastar irremediavelmente os dois personagens, é determinante para aproximá-los. Durante um primeiro momento, eles realmente se distanciam. Contudo, apenas o suficiente para que a informação fosse digerida pelo protagonista. A menina é um contraponto fantástico do protagonista. Assim como ele, a vampira não possuía amigos, sofria por sua inadequação social e compartilhava uma recorrente solidão por conta de sua condição. "Eli também parece estar completamente desconectada de sua própria espécie [outros 
vampiros]" (WRIGHT, 2010, p. 59), o que faz o paralelo com menino ser ainda mais direto. Mais a frente, ao beijar a boca ensanguentada da garota após ter a salvo e auxiliado indiretamente em um assassinato, Oskar conseguirá finalmente realizar o pacto que desejava.

A figura do vampiro é utilizada na narrativa como uma metáfora para o estranho, o recluso. Como apontado no estudo de José Luiz Aidar e Márcia Maciel (1986), desde sua origem o imaginário vampiresco era destinado para humanos que fugiam a normas e padrões: "Sem dúvida, quem pagava o pato eram os suicidas, os malditos, os bruxos, os excomungados e sacrílegos; enfim, aqueles cujas singularidades não eram consideradas exemplares" (ibid., p.14). Tal qual sua amiga caçada pela sociedade, Oskar é taxado como vítima dos seus algozes na escola por ser diferente.

Temas comuns às narrativas iniciáticas como a delimitação visível dos âmbitos dos adultos e das crianças, e uma relação conturbada entre o protagonista e seus próprios pais são encontrados na obra. "Embora a narrativa se concentre nas duas crianças, a maioria dos personagens adultos do filme também são reclusos ou não tem contato significativo com os outros" (WRIGHT, 2010, p. 59). A relação de Oskar com sua mãe, por exemplo, é mostrada de forma bastante distanciada. Os dois personagens nunca estão no mesmo cômodo ou em um plano conjunto. Nos únicos dois momentos onde essa lógica é subvertida, nenhum diálogo significativo ocorre. A mãe parece não perceber a origem dos diversos hematomas que vão regularmente surgindo no filho em decorrência das violências sofridas na escola - conferindo um caráter relapso a sua personagem.

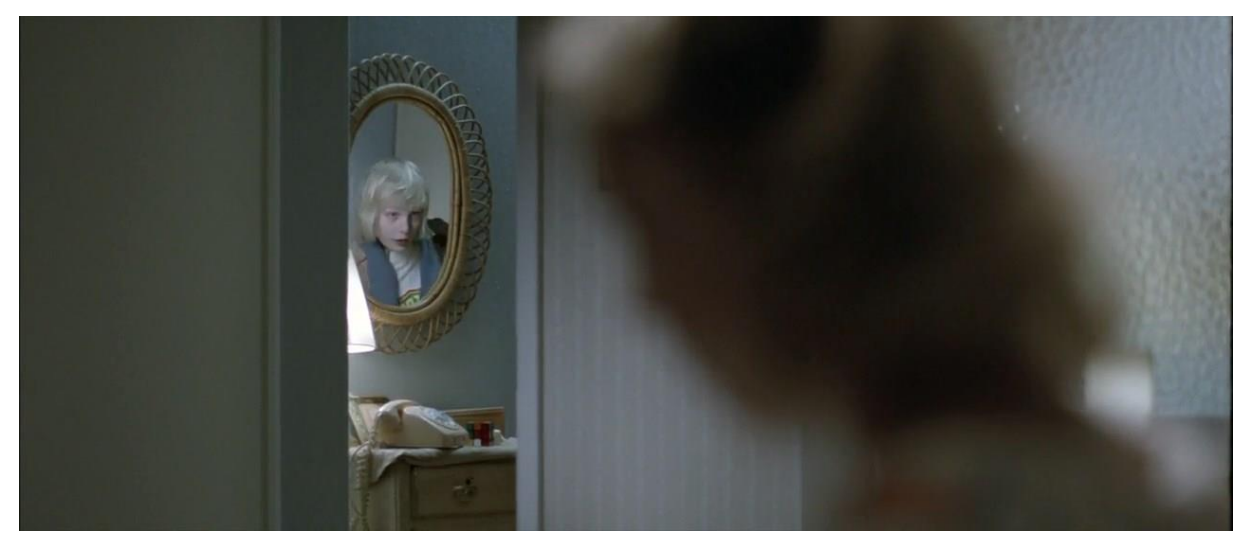

Oskar observa sua mãe através do reflexo de um espelho — Frame extraído do filme "Deixa Ela Entrar". 
O lugar ocupado pela personagem Eli é o mais interessante de ser observado enquanto narrativa iniciática. Por ser uma vampira e não pertencer nem ao núcleo dos adultos por conta de sua aparência de doze anos, nem ao das crianças por ter a mesma idade há muito tempo; a ela é dado um não-lugar durante a história — semelhante ao da personagem Claudia em Entrevista com o Vampiro (1994) de Neil Jordan. Ela subverte o esperado: dá ordens ao seu responsável mais velho; e transita livremente entre os dois mundos. A divisão ainda assim é clara: o universo infantil que compartilha com Oskar é o lugar de descobrimentos e prazeres; o universo dos adultos é destinado à violência e sobrevivência (matar ou morrer). É do encontro entre essas duas esferas intermediado por Eli que resulta no amadurecimento do menino Oskar e, portanto, sua assimilação da morte e violência.

Ao ser analisada como uma narrativa iniciática costumeira, encontraremos algumas problemáticas específicas da obra.

Na resolução usual das histórias de amadurecimento, experiências adversas levam o protagonista à maturidade psicológica e à integração social. Em "Deixa Ela Entrar", o mundo dos adultos é rejeitado inteiramente, no momento em que Oscar e Eli se voltam apenas um para o outro. (ibid., p. 62)

$\mathrm{Na}$ história de Oskar, mais importante do que seu contato inicial com a morte ou o amadurecimento decorrente dele, é a maneira com que a violência de seu cotidiano é absorvida pelo personagem que o influencia. Estando o menino imerso em um ambiente onde é agredido regularmente sem razão e carregado de um clima de paranóia em consequência da onda de assassinatos, Eli surge como uma incentivadora para os seus impulsos violentos. Por conta disso, mais do que concluir a história com a despedida entre o garoto e a vampira, precisamos testemunhar as consequências desse contato. Esses resquícios surgem durante a sequência da piscina, onde o protagonista se vê em uma intensa situação: ser ameaçado pelo irmão mais velho de seu antigo agressor.

Ao pensar que havia conseguido resistir a toda violência que o cercava, Oskar se vê em meio a mais extrema delas: precisar se decidir entre um quase afogamento ou perder a visão de um de seus olhos. A violência atinge o seu incompreensível auge para o personagem. Nesse momento, Eli ressurge trazendo consigo toda a morte e brutalidade que simboliza, ocasionando um choque no universo distinto do garoto. Oskar, então, ao contrário dos protagonistas das narrativas iniciáticas, decide por 
recusar o outro universo, o dos adultos, e permanecer no não-lugar habitado por Eli. Ambos os personagens encontram forças e semelhanças em suas próprias solidões.

A morte surge na obra personificada na personagem de Eli. É através de sua inesperada chegada durante a noite que o cotidiano banal e melancólico do protagonista se altera. Ela desperta o protagonista de sua passividade. A personagem vampiresca se torna responsável pela gradual perda da inocência de Oskar - mesmo que por vezes dê indícios de sua recusa em fazê-lo, "porque ela é tanto uma criança, quanto um predador relutante" (WRIGHT, 2010, p. 62).

É importante observar a presença entre o grupo dos valentões de um menino que demonstra ser recém-chegado ao bando. Por vezes, ele demonstra incômodo durante as humilhações contra o protagonista. Ao ser comandado a golpear Oskar com uma vara, por exemplo, o garoto se opõe em um primeiro momento, mas acaba o agredindo mesmo a contragosto. Em seu estudo sobre bullies na ficção contemporânea, Clare Bradford e Lara Hedberg (2018) apontam que "personagens representados como valentões relutantes ou ambivalentes recebem desfechos positivos" (p. 119). Tal constatação se prova presente na obra tendo em vista que, ao fim, o garoto é o único entre o grupo de valentões a ter a sua vida poupada pelo massacre realizado por Eli.

\section{3 - A inocente crueldade}

A primeira vista, é uma tarefa árdua aproximar obras tão distintas. Do país de origem à década de lançamento, todos os detalhes que cercam os dois filmes parecem apontar para caminhos opostos. Enquanto em Deixa Ela Entrar encontramos uma releitura do mito vampiresco para retratar a solidão, Brinquedo Proibido tem seu foco nas violências da guerra e nas significações de rituais.

Uma aproximação inicial ocorre durante a análise dos personagens Eli, a vampira-criança, e Michel, o menino interiorano. Ambos assumem um papel muito

semelhante em suas narrativas. É permitido a esses personagens transitar entre o domínio que pertencem (universo das crianças) e o posterior (universo dos adultos) por conta de suas especificidades. É através deles que os protagonistas das duas obras conseguem atravessar as etapas de seu próprio rito de passagem para o amadurecimento. 
Eu denomino esse tipo de personagem de polivalente por conta de sua natureza versátil derivada da liberdade que possui em transitar entre universos distintos. Essa liberdade é presenciada, por exemplo, quando Michel assume o papel de tradutor entre os membros de sua família e a menina Paulette.

Tanto o menino Oskar com seu fenótipo sueco, quanto à protagonista de Brinquedo Proibido com sua aparência angelical, conseguem fazer ações consideradas ruins pela sociedade que os cerca e, ainda assim, não serem punidos por seus atos. Eli "separada dos nórdicos de cabelos loiros e claros pelo seu cabelo despenteado e escuro e por sua aparência desleixada e desgrenhada" (WRIGHT, 2010, p. 59) sofre graves sanções em sua trajetória: sendo caçada e presenciando a morte de seu companheiro de viagem. Por mais que tenha dividido com a menina Paulette o roubo das cruzes, Michel é o único castigado através de punições físicas e repreensões verbais. Mais do que isso, em dado momento de ambas narrativas Eli e Michel são caçados. O auxílio que ofertam aos protagonistas desequilibra a livre movimentação que anteriormente possuíam aos domínios da infância e dos adultos.

A crueldade surge, direta e indiretamente, durante a trajetória de ambas as narrativas como uma tentativa de seus protagonistas processarem toda a violência na qual estão imersos. A morte não surge como elemento isolado. Oskar e Paulette não possuem um ambiente propício para seguir as etapas rotineiras do luto. Enquanto o menino solitário faz amizade com uma incontrolável e assassina criatura, a recém-órfã se encontra imersa em uma cultura de guerra onde todos ao seu redor se encontram entorpecidos pela recorrente presença da morte.

Os dois protagonistas, ao fim, rejeitam o universo apresentado pelos adultos e, consequentemente, o amadurecer. Oskar foge em companhia da Eli e deixa para trás todos os detalhes pregressos de sua vida como família e escola. Já Paulette, por mais que seja enviada para um orfanato de garotas, clama pela única pessoa que aparenta compreendê-la: Michel — uma negação a sua nova realidade imposta pelos adultos. 


\section{CAPÍTULO 3: O suicídio como anti-narrativa iniciática}

No decorrer de suas histórias, as narrativas iniciáticas visam acompanhar o desenvolvimento de seus protagonistas da infância para a adolescência. Por mais que a morte surja eventualmente nessas obras como um disparador desse amadurecimento, o aspecto fundamental reside na travessia efetuada pelos personagens principais do domínio infantil para o reino dos adultos — podendo ocasionalmente não ocorrer de forma completa. Nessas obras que possuem a morte como motif, nota-se uma importante vinculação entre a compreensão do fim da vida e o rito de passagem dos personagens. Como visto, essa relação pode sofrer interferência de adultos por sua omissão como é o caso de Deixa Ela Entrar ou por excesso de envolvimento como em Brinquedo Proibido, ocasionando, em ambos os casos, a escolha da criança por permanecer na esfera dos infantes e, assim, adiar a inevitável transição.

De outro modo, a morte pode se apresentar nas narrativas iniciáticas em sua forma mais extrema: o suicídio infantil. Ao contrário das obras onde a criança perde a vida por razões externas como na animação Túmulo dos Vagalumes (1988) ou que o suicídio é apenas o ponto de partida para a trama como em Miss Violence (2013), examinaremos filmes onde os protagonistas optam conscientemente por retirar a própria vida.

Para iniciar a reflexão sobre o papel do suicídio infantil nessas narrativas, podese tomar como ponto de partida a provocação feita pela Dra. Evelyn Kuczynski (2014): "Seria o suicídio na infância uma "crônica da morte anunciada" (via final de toda uma vida de abusos, psicológico, físico e/ou sexual)?” (p. 249). A atitude de findar com a própria vida seria a resposta definitiva dos personagens para os problemas encontrados durante sua vivência e amadurecimento? Assim como Kuczynski aponta em seu artigo, o suicídio contém características multifacetadas e, por conta disso, não admite um diagnóstico simplório, "implicando desde fatores sociais (credos religiosos, família, política, grupos sociais), disposições organopsíquicas, [e] características do ambiente físico" (ibid., p. 246).

Os filmes que retratam suicídios ocorridos na juventude comumente apresentam dois aspectos em sua abordagem da morte durante as narrativas: refletem sobre a vida 
pregressa dos jovens em um estudo das prováveis causas de suas mortes e evitam definir de maneira concreta as razões que levaram seus personagens a realizar tal ato. $\mathrm{O}$ segundo tipo é o caso do filme de estréia da diretora Sofia Coppola: As Virgens Suicidas (1999). Na obra, cinco irmãs de diferentes idades são vigiadas pelos olhos atentos de seus repressores pais, terminando por se suicidarem cada uma a sua maneira. Essa prática de transformar em incógnita as causas que levaram cada uma das irmãs a retirarem a própria vida é chamada pelo professor Bert Cardullo (2001, p. 639) de "angústia adolescente generalizada";

Digo angústia "generalizada" porque o filme de Coppola, paradoxalmente, quer retratar
as mortes dessas meninas como (1) misteriosas e (2) sintomáticas de algo gravemente
errado na sociedade como um todo. No entanto, não há mistério real, já que a mãe dessa
prole é duramente autoritária, [...] enquanto o pai, um instrutor de matemática, é
astigmático, ineficaz e indefinido. [...]. Para completar, a família é estritamente religiosa
a e as irmãs vão para o colégio católico onde o pai leciona. (ibid., p. 639)

Essa representação narrativa tem como intuito transportar a discussão sobre a provável razão pelo suicídio para a esfera da vida social que cerca os protagonistas enquanto amadurecem. De certa forma, o suicídio surge nas narrativas iniciáticas como uma firme negação aos arcos narrativos de amadurecimento; uma recusa definitiva dos protagonistas em abandonar a infância e se integrar ao universo dos adultos. Ao se matarem, os personagens interrompem a própria travessia em direção a maturidade impedindo irrevogavelmente que consigam consumar seus ritos de passagem; que continuem a vivenciar uma infância que, para eles, pode já ter sido dolorosa o suficiente.

Será que, após certo nível de violência, a criança não é mais uma criança; o futuro não é mais um futuro? Pelo menos, torna-se difícil, senão impossível, imaginar um futuro. Pode ser que esta seja a estrutura do sentimento que, assombrando a morte de uma criança em sua singularidade irredutível, está implícito no investimento na imagem da criança como sinal do futuro, como defesa contra a perda de significância no mundo (LEBEAU, 2008, p. 179).

As duas obras analisadas nesse capítulo possuem particularidades bastante distintas ao tratar sobre o assunto. Ainda assim, eles conseguem dialogar de forma bastante interessante com o questionamento feito por Kuczynski. Cada qual a sua maneira, o suicídio infantil se apresenta em ambas as obras como uma crônica de uma morte anunciada.

Em Alemanha, Ano Zero (1948), o jovem protagonista desbrava uma Berlim devastada e sem esperança. Através do choque que ocorre entre a visão lúdica que possui e os problemas pós-guerra que se vê obrigado a dividir com a família, o menino é 
coagido a tomar decisões sérias que surtirão graves consequências para a sua vida. $\mathrm{O}$ suicídio surge na obra em seu encerramento, oferecendo uma fuga para as escolhas feitas pelo menino em uma terra arrasada.

Em O Porco Espinho (2009), uma pequena moradora de um luxuoso apartamento parisiense decide que irá se matar ao completar 12 anos. Logo nos primeiros minutos, a idéia do suicídio surge anunciada pela própria protagonista. A narrativa acompanha a jovem durante o seu caminho de descobrimentos, onde irá repensar sobre a sua própria decisão conforme entra em contato com indivíduos diferentes daqueles que tanto abomina.

\section{1 - Alemanha, Ano Zero e o suicídio como escape}

Para uma reflexão mais apurada sobre a obra, uma análise sobre o período histórico em que foi realizada e sobre seu realizador, Roberto Rossellini, pode melhor nos orientar.

Antes mesmo de despertar a atenção em nível mundial por conta de suas obras neo-realistas, Rossellini já havia atuado em diversas funções da produção cinematográfica como roteirista, assistente de direção e realizador de documentários. Um dos integrantes mais célebres do neo-realismo italiano, o diretor foi considerado por Federico Fellini como o único cineasta neo-realista ${ }^{4}$ e seu filme "Roma, cidade aberta" de 1945 é considerado como marco inicial do movimento cinematográfico. Ainda existe uma grande dificuldade em definir esse conjunto de obras como um movimento cinematográfico ou escola, mas podemos reiterar, assim como Mariarosaria Fabris (2006, p. 216), que "na Itália, entre 1945 e 1952, à margem da produção cinematográfica tradicional, houve uma série de realizações que tentaram fazer com que o público refletisse sobre as relações entre o homem e a sociedade".

\footnotetext{
4 “Seu abandono em relação à realidade, sempre atento, límpido, fervoroso, aquela sua forma de se situar com naturalidade num único ponto impalpável e inconfundível entre a indiferença do distanciamento e a falta de habilidade da adesão, permitia-lhe capturar, fixar a realidade em todos os espaços, olhar o interior e o exterior das coisas, desvendar o que a vida tem de inalcançável, de misterioso, de mágico. Por acaso o neo-realismo não é isso? Daí, quando se fala de neo-realismo, só se pode falar de Rossellini. Os outros fizeram realismo, verismo ou tentaram traduzir um talento, uma vocação, numa fórmula, numa receita. (FELLINI, 2000, p. 76)
} 
As obras neo-realistas buscavam um diálogo maior com o grande público almejando uma reflexão da população sobre a realidade pós-Segunda Guerra Mundial onde se encontravam. Sob esse pano de fundo foi lançado, em 1948, Alemanha Ano Zero, filme de encerramento da Trilogia da Guerra de Rossellini. Muitos das características de obras anteriores do diretor se encontram presentes nesse filme: o olhar documental adquirido em seus primeiros trabalhos e a utilização de atores nãoprofissionais, caso de seu protagonista.

Sobre a recorrência de escalação de atores infantis não-profissionais em obras neo-realistas, Cardullo (2015, p. 11) escreve que

[...] o neo-realismo - e o "novo neo-realismo" como vemos hoje em dia, tanto na Itália como em países distantes dela - substitui a ênfase cinematográfica tradicional nas complexidades psicológicas do indivíduo excepcional ou único, com o desejo de investigar o cotidiano do humano comum em seu contexto social, político e econômico. [...] Isso porque o tema essencial do cinema neo-realista é o conflito entre a pessoa comum e anônima e as imensas forças sociais - guerra, política, crime organizado, economia - que são completamente externas a ele, mas determinam completamente a existência desse indivíduo. As vítimas mais lamentáveis de tais forças, porque são as mais inocentes, são naturalmente crianças e, portanto, não é por acaso que filmes neorealistas importantes, tanto italianos quanto internacionais, são protagonizados por elas.

Em Alemanha Ano Zero acompanhamos Edmund Köhler (Edmund Moeschke), um menino de 12 anos que habita uma devastada Berlim pós-Segunda Guerra Mundial. Edmund divide um apartamento junto a outras nove pessoas. Entre elas estão o seu adoecido pai, sua conscienciosa irmã e seu irmão mais velho que, por conta do seu envolvimento com o exército de Hitler, tem medo de se apresentar às autoridades após o fim da guerra. Enquanto seu irmão se esconde dentro de um quarto e seu pai definha preso a uma cama, o personagem principal busca maneiras de conseguir dinheiro e mantimentos para ajudar o resto de sua família. Através de saídas noturnas e encontros com soldados norte-americanos, a irmã do menino também obtém ajuda para o sustento de todos os outros membros.

Através de seus planos iniciais, Rosselini consegue transmitir a sensação de uma cidade devastada. As ruínas de Berlim dividem o protagonismo com Edmund desde os minutos iniciais da obra. Ela será de grande importância para que, ao fim, o personagem consiga tirar a própria vida. Já na primeira sequência com a presença do menino, é salientado o seu não pertencimento ao mundo dos adultos. É negada ao personagem a chance de trabalhar junto aos demais por culpa de sua pouca idade. A separação entre 
adultos e crianças é constantemente relembrada ao jovem Edmund, mesmo em um território devastado pela guerra como o qual ele se encontra.

A figura do mentor surge para o protagonista personificado em um antigo professor. $\mathrm{O}$ homem encontra o garoto em um dos momentos de maior fragilidade de Edmund: não havia conseguido realizar a troca de uma balança que havia prometido. $\mathrm{O}$ professor se prontifica a ajudá-lo. Ele exerce a função de orientador do personagem para o mundo dos adultos. Já nessa primeira aparição, o professor possui um subtexto pedófilo e tenta transmitir ao protagonista os ideais nazistas aos quais defende. Percebemos a dualidade existente entre o docente e o pai de Edmund: enquanto o educador legitima o nazismo, descobrimos que o homem acamado havia forjado um certificado falso para que o menino não fizesse parte da juventude hitlerista. O professor é o responsável por apresentar Edmundo a outros dois jovens que se provam tão corruptos e corrompidos quanto toda a sociedade que os cerca - realizando roubos de carga e furtando outros cidadãos. É do irmão mais velho de Edmund, considerado como um espelho moral pelo protagonista, que parte pensamentos niilistas e a única sugestão de suicídio que ocorre durante a narrativa.

Durante um abalo na relação entre Edmund e seu irmão mais velho, após ter sua índole questionada recorrentemente pela irmã por não querer se entregar as autoridades, o protagonista procura mais uma vez seu mentor, o professor. Durante essa segunda visita, o professor, que se encontra com outro garoto, propaga de maneira mais veemente suas convicções. Ele chega a sugerir que o garoto deixe que o próprio pai morra, visto que "nós todos temos que morrer, mais cedo ou mais tarde".

No hospital, Edmund ouve o patriarca confessar seu próprio desejo de morte deixando, assim, de ser um fardo para os outros membros da família. A morte começa a se desenhar como uma forma de liberdade e negação aos horrores que rodeiam seus personagens. Ao ouvir o lamento, o protagonista rouba um frasco de remédio do hospital pensando em realizar tanto o desejo de seu próprio pai, quanto a sugestão dada por seu professor. De volta ao apartamento, Edmund prepara o chá da morte. O patriarca da família falece concomitantemente ao momento em que o irmão de Edmund se entrega às autoridades. Quando retorna, livre, da delegacia após ter se apresentado às autoridades, o irmão mais velho descobre sobre a fatalidade que abateu sobre a sua 
família e é questionado por Edmund: “ele está livre agora?”. O protagonista sinaliza novamente sua associação entre morte e liberdade.

Após perceber que tomou uma decisão irremediável ao matar o próprio pai, o protagonista sai pelas ruas de Berlim procurando as amizades que outrora haviam o acolhido. Todos os personagens parecem lembrar o protagonista de sua pouca idade no ato final da obra. "Você parece que esqueceu que é apenas uma criança", diz seu irmão mais velho. Ao encontrar com a menina apresentada pelo professor, ele é veementemente rejeitado: “eu não saio por aí com garotinhos”. Precisando confessar seu pecado, Edmund procura o mentor para compreender o que poderia fazer. Nesse momento, o menino descobre a manipulação que havia sofrido. O homem se desespera quando o garoto revela que concretizou sua sugestão e deu fim a vida do pai. Desacreditado com todos os adultos que o cercam, o protagonista foge.

Andando solitário pelas ruínas da cidade, Edmund se depara com um grupo de meninos jogando futebol. Ao tentar brincar na companhia deles, as crianças o rejeitam. O protagonista não pertencia mais ao mundo delas e os adultos que conhecia também o haviam rejeitado. O menino se encontra em um limbo identitário, reservado aqueles que não realizaram completamente o rito de passagem em direção ao amadurecimento. Ele havia ido longe demais para um adulto e mais ainda para uma criança.

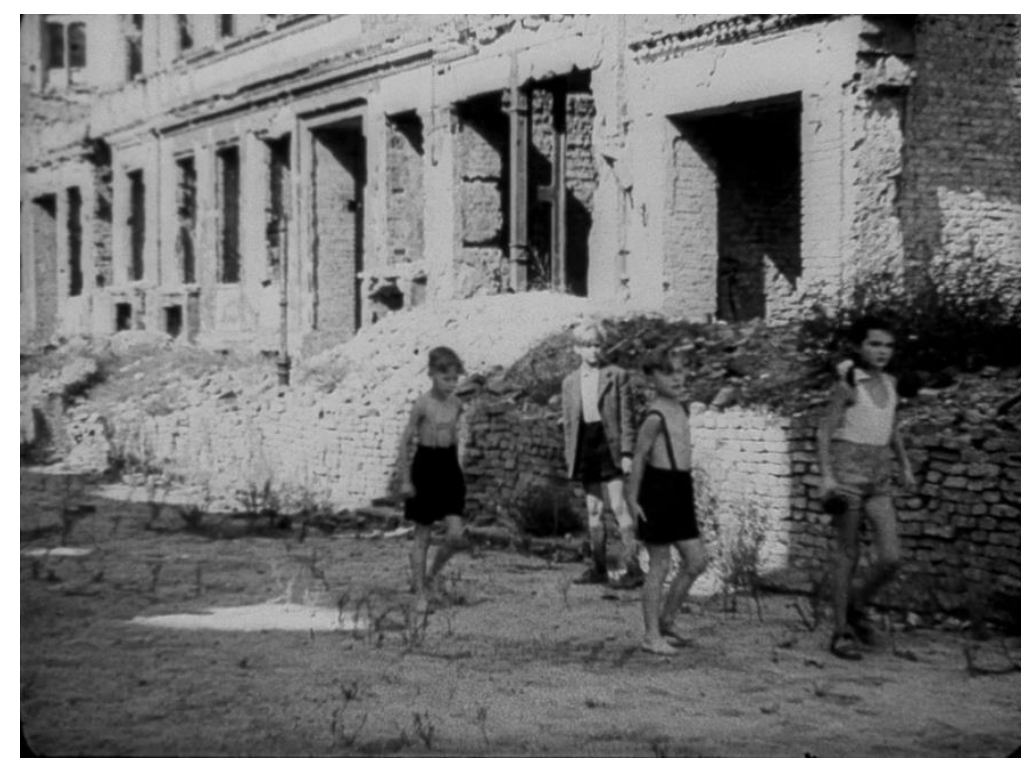

Edmund rejeitado pelo mundo das crianças — Frame extraído do filme "Alemanha, Ano Zero". 
Enquanto continua sua solitária caminhada, o protagonista também tem contato com a moral cristã que havia se mostrado omissa durante toda a narrativa. Os habitantes da cidade, junto ao garoto, admiram os sons da igreja. $\mathrm{O}$ final de cunho pessimista pode ser compreendido como a perspectiva do próprio realizador em relação ao panorama que se desenhava na sociedade da época. "Perdido, corrompido e - como o povo alemão — sem salvação, Edmund não vê nenhum futuro possível para si ou para a nação e, portanto, comete suicídio” (KEENE, 2016, p. 101). Como apontado,

[...] a derrota histórica do povo já vinha sendo pressentida pelos principais diretores neo-realistas: tanto Rossellini como Visconti e De Sica encerravam suas obras mais fecundas sobre a falta de uma perspectiva de um futuro melhor para os personagens populares ou sobre sua renúncia (ou adiamento) a lutar por mudanças sociais (FABRIS, 2006, p. 198).

A morte surge em Alemanha Ano Zero tanto como um símbolo de liberdade, quanto uma renúncia ao futuro desacreditado destinado aos cidadãos de uma cidade devastada. Edmund rejeita o futuro que é ofertado a ele pelo mundo dos adultos e se encontra excluído entre seus pares: as outras crianças.

Em um momento da narrativa, ao lamentar o fato de estar inválido e não conseguir ajudar ativamente, o pai indaga ao seu filho mais velho: "você compreende que seu irmão [Edmund] está carregando nas costas todo o fardo de nossa existência?”. Esse questionamento norteia toda a narrativa, onde o protagonista parece carregar o fardo da existência não só de sua família, mas de toda uma sociedade desacreditada. Ele é o responsável por realizar os desejos mais sombrios dos personagens que encontra o lamento de morte expressado pelo próprio pai, por exemplo - ao mesmo tempo em que é um dos poucos que tenta de todas as maneiras cuidar dos membros de sua família. Ele sofre por ser íntegro como seu pai e mais corajoso do que sua figura inspiradora, o irmão mais velho. $\mathrm{O}$ protagonista parece funcionar como uma relação entre o presente de uma cidade devastada e seu passado nazista; impedindo que essa memória assombrosa seja esquecida. 


\section{2 - O Porco Espinho e a discreta tristeza da burguesia}

"Todas as famílias felizes são iguais. As infelizes o são cada uma à sua maneira". Através dessa recorrente citação ao romance russo "Anna Karenina", a narrativa pontua o questionamento vivido pela pequena Paloma (Garance Le Guillermic). A protagonista revela, logo nos minutos iniciais da projeção, que tomou a decisão de se matar no dia de seu aniversário de 12 anos. Sua escolha é decorrente das incongruências presentes no estilo burguês de alta classe vivido tanto por ela, quanto pelo resto de sua família. A jornada da personagem será impulsionada não por conta de seu desejo por amadurecimento, mas, ao contrário, por seu anseio inicial por não envelhecer e se tornar semelhante qualquer um dos adultos que a cerca. Paloma habita o cenário habitual dos Bildungsroman e nega cada um de seus aspectos.

A protagonista, em uma espécie de declaração final para o mundo, captura imagens documentais do universo dos adultos. Nessas imagens, a menina demonstra através de suas narrações as contradições e absurdos que envolvem o mundo dos mais velhos. Ela observa a mãe com seu vício em antidepressivos - misturando-os com bebidas alcoólicas. Também analisa o pai o descrevendo como "mais preocupado com a carreira do que com a sua família, mas bem intencionado". A menina sente que não possui espaço para diálogo entre os seus familiares. O filme realizado por ela serve como estudo sobre o que o seu futuro reserva, caso não tire a própria vida.

Para auxiliar a menina em busca de um novo olhar sobre os adultos e a morte, apresentam-se o japonês Kakuro Ozu (Togo Igawa) e Renée Michel (Josiane Balasko). Ozu é um recém-chegado que, por conta de sua vivência pregressa, contraria a segregação de classes feita pelos outros moradores do prédio. Renée é a zeladora do edifício que por conta de seus muitos anos de serviço, já internalizou as discriminações impostas a ela pelos inquilinos. O recém-chegado e a zeladora se unem através da paixão em comum que possuem pelos livros e filmes - momento em que citação de Anna Karenina é proferida pela primeira vez.

A relação entre Ozu e Renée reverbera de forma bastante potente no cotidiano de

Paloma. É importante perceber como a menina constrói suas relações com os outros dois personagens ao longo da narrativa, já que cada uma delas dialoga com as discriminações que a menina quer abolir. Em um primeiro contato, a personagem 
principal rejeita uma proximidade com o novo morador durante uma conversa realizada no elevador. Ela muda de opinião quando o homem visita sua casa a procurando para conversar, e não aos seus pais, visto que a menina conhecia um pouco do idioma nipônico. Esse convite literal para um diálogo faz com que os laços entre os dois se estreitem.

A zeladora e a menina, entretanto, somente se relacionam mais profundamente em um ponto mais avançado da narrativa. Através de suas declarações, Paloma dá indícios de, ao contrário dos outros residentes do prédio, ter enxergado além das aparências de Renée. Em um ponto, a menina confessa a Ozu sua opinião sobre a funcionária: "Sra. Michel me lembra um porco espinho. Por fora é coberta de espinhos, uma fortaleza real. Todavia, por dentro, é tão refinada quanto este animal enganosamente indolente, extremamente solitária e terrivelmente elegante". Para que a relação entre Paloma e Renée se desenvolva, Ozu auxilia na derrubada das barreiras mentais da zeladora. Através dos encontros entre Ozu e Renée, as barreiras de classe, tão predominantes na propriedade, são dissipadas. A direção pontua esse acontecimento em momentos como, por exemplo, ao exibir a funcionária, em uma visita ao apartamento de Ozu para um jantar, tirando seus sapatos e colocando uma sandália igual a que o homem utilizava. Ação que simboliza a visão de igualdade praticada pelo morador.

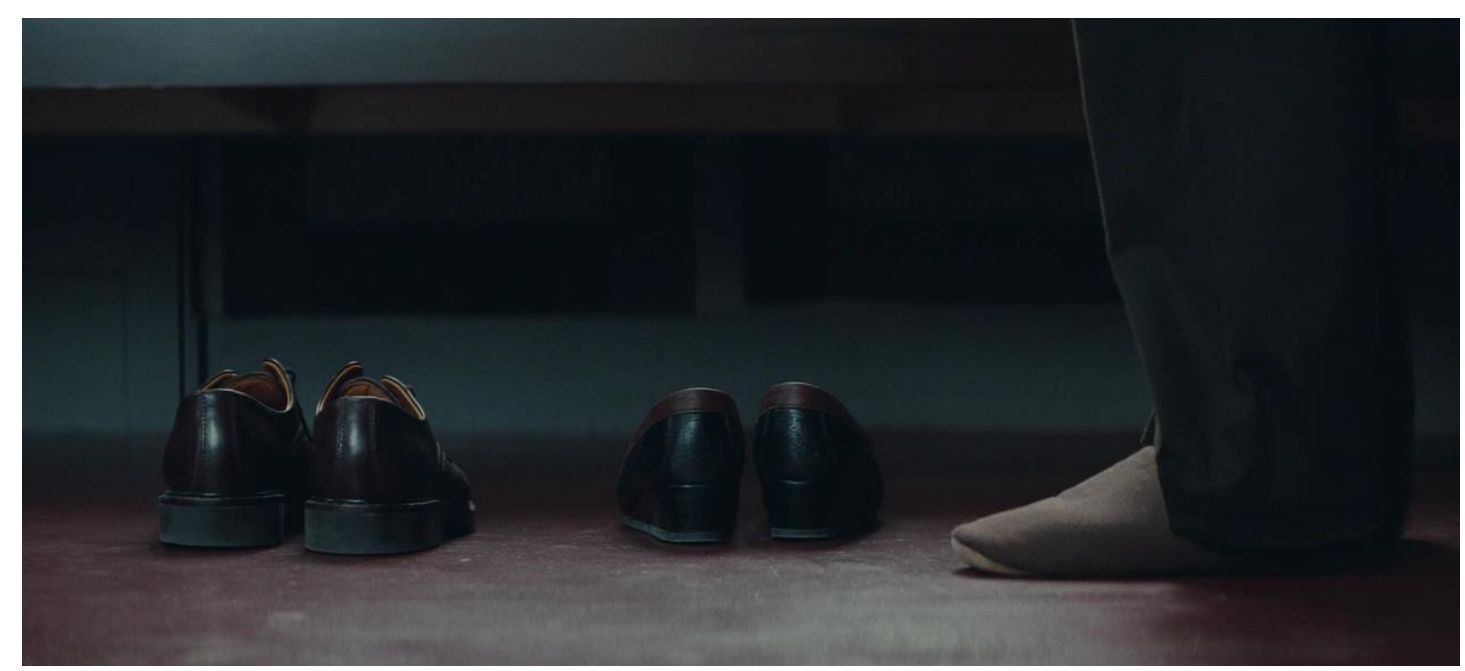

Um lugar de igualdade — Frame extraído do filme "O Porco Espinho".

A personagem de Renée surge em "O Porco Espinho" como um contraponto para tudo que Paloma mais despreza em todos adultos que a rodeiam. O apreço da senhora pela intelectualidade é percebido por Paloma no momento em que a garota, 
esgueirando sorrateiramente pela habitação da zeladora, descobre que Renée está lendo "Elogio da Sombra". O livro fomenta o interesse da personagem principal pela senhora e, ainda, cria uma ligação entre a funcionária e Ozu, visto que a obra é escrita por Jun'ichirō Tanizaki, um dos escritores japoneses mais populares. Em consonância a essa descoberta, Paloma é silenciada em sua própria residência ao tentar consertar o erro proferido pelo sogro de sua irmã sobre a origem chinesa do jogo Go. Rapidamente levada até o seu quarto, ela é repreendida pelo próprio pai através de um irritado "Abstiens-toi!" mais um paralelo entre a relação entre os dois e o ambiente repressor de sua residência.

Conforme realiza sua trajetória e entende mais sobre o amadurecimento e a morte, a protagonista segue registrando a própria vida e construindo seu próprio imaginário dos personagens ao seu redor através das lentes de sua câmera.

[...] é Paloma que terá através de seu olhar e suas lentes a oportunidade de criar sua própria Renée, a trabalhadora que subverte o vaticínio da voz que emana do capitalismo e lê, escreve, aprecia artes plásticas, cinema, isto é, tem uma vida subjetiva rica que é resiliente ao poder esmagador do trabalho assalariado (VICENTE e MAGALHÃES DOS REIS, 2016, p. 4.322).

Renée será responsável por inspirar e conduzir Paloma entre seus questionamentos sobre a alta classe a qual pertence, oferecendo novos entendimentos sobre vida e morte. Podemos notar a importância de Renée para a protagonista ao presenciamos a revelação da garota de sua vontade em se tornar uma zeladora quando crescesse. Uma sequência que evidencia dois aspectos bastante interessantes. $\mathrm{O}$ primeiro é a confiança existente entre as duas personagens, já que Paloma revela sua ambição apenas para Renée e a sua própria família. A segunda é o indício de que a menina estava reconsiderando sua decisão em se matar, conseguindo ter planejamentos para o futuro.

Assim como em Virgens Suicidas, "quanto ao suicídio juvenil como um sintoma de mal-estar social, o filme descreve o sintoma, mas não penetra em nenhuma causa fora do círculo familiar" (CARDULLO, 2001, p. 639). Além dos membros de sua família, os únicos personagens que interagem com a jovem Paloma são Renée e Ozu ambos surgidos pós-decisão de suicídio. Podemos apenas conjecturar sobre a rotina fora das paredes do prédio onde vivem. Nenhum colega de escola tem qualquer contato com a menina, assim como a escola não emite nenhum comunicado para os pais. Seu

\footnotetext{
5 "Contenha-se!"
} 
cotidiano escolar parece ocupar um espaço irrelevante em sua decisão por tirar a própria vida, por mais que vejamos o interesse que a protagonista sente pelas artes e filosofia. Tais fatos podem nos revelar certa infantilidade, em relação ao desejo pela própria morte - contrastando com a personalidade tão madura da protagonista.

Paloma não compreende o caráter fatal e irremediável do suicídio. Em alguns momentos, acompanhamos a sua relação que beira quase ao fascínio com o ato de morrer. Ela encena de maneiras variadas as formas com que pode tirar a própria vida: simula um ataque do coração ao subir as escadas, tal qual o que ocasionou o falecimento de seu antigo vizinho; admira o asfalto enquanto está de pé na beirada da janela do próprio quarto cogitando a possibilidade de se jogar; e atravessa a si mesma com uma espada imaginária como se realizasse o Seppuku, o suicídio destinado a guerreiros japoneses - possível relação com sua proximidade com o Ozu.
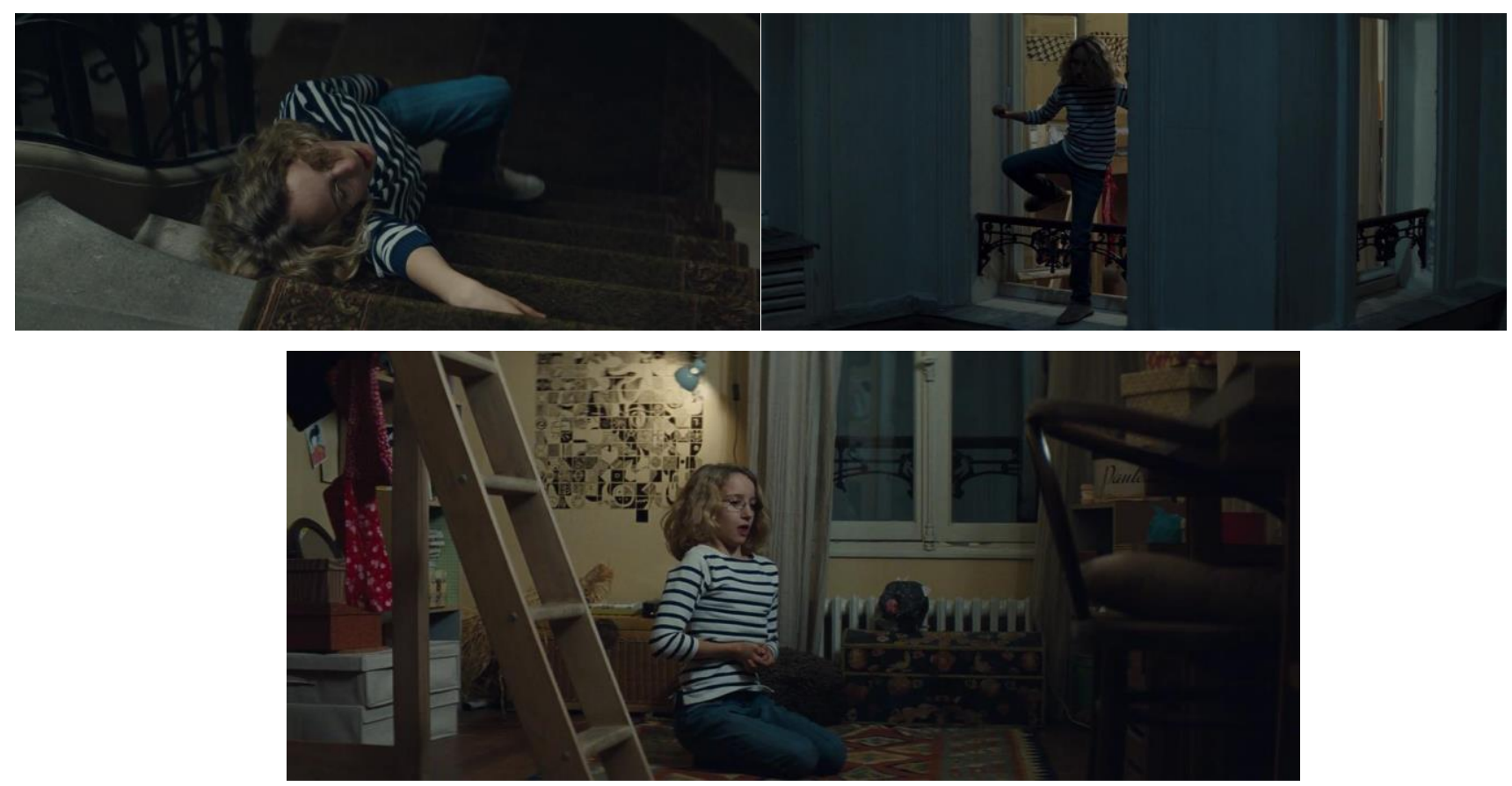

As fantasias de morte de Paloma — Frames extraídos do filme "O Porco Espinho".

A morte surge na trajetória de Paloma junto ao tema de renascimento. Através de sua relação com Renée e Ozu, a menina vai ampliando o seu ponto de vista sobre o mundo que a cerca e criando para si mesma uma nova persona. Uma relação direta entre amadurecimento e a morte do seu antigo eu, mais novo e infantil. Ao conhecer a neta mais nova de Ozu, Paloma se questiona se "há uma chance de alguém se tornar o que ainda não é”. Um diálogo interno movido por sua rejeição ao mundo adulto destinado a, 
aparentemente, todos os integrantes de sua família e que a está aguardando. É a partir dessa reflexão que a protagonista — anteriormente, encarando a morte como única saída - consegue enxergar novos horizontes. O futuro não é necessariamente escravo do presente.

O peixe dourado pertencente à irmã de Paloma possui um importante papel na jornada da protagonista por expor as consequências atreladas à morte. Após ponderar sobre a vida do peixe preso ao aquário, a menina decide libertá-lo definitivamente. Dando um comprimido ao animal da mesma forma que planejava se matar, Paloma causa a sua suposta morte e se desfaz do cadáver no vaso sanitário. Quando sua irmã percebe o desaparecimento de seu peixe dourado, a protagonista se confronta com algo novo: o luto. Paloma não pensava nas consequências de sua própria morte para os familiares. É importante para a personagem se deparar com o luto ao ver sua irmã preocupada com a morte do peixe por funcionar como uma preparação para os acontecimentos futuros - por mais que o diálogo entre as duas se conclua em um acordo aparentemente banal. O peixe dourado, inclusive, funcionará como o símbolo do renascimento vivido por Paloma que descobrirá depois que o animal não morreu e foi resgatado e cuidado por Renée - muito semelhante à própria relação da protagonista com ela.
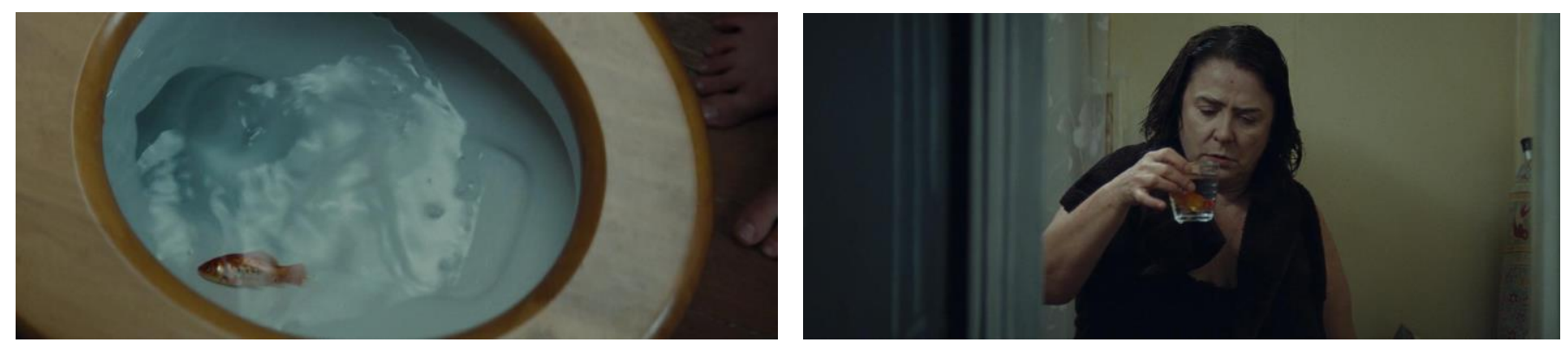

Peixe como simbolismo de renascimento — Frames extraídos do filme "O Porco Espinho".

O acidente fatal de Renée é o ponto-chave para que Paloma se decida sobre dar ou não fim a própria vida e conclua seu amadurecimento/renascimento. É a partir da morte da zeladora que a protagonista reavalia o seu entendimento infantil sobre o fim da vida: "É isso que é a morte? Você não vê mais aqueles que ama, não vê mais aqueles que te amam. Se morrer é assim, é realmente trágico como as pessoas dizem”. Assim como foi a responsável por impedir que Paloma fosse atropelada ao saírem juntas e, também, sido parte integrante no salvamento do peixe dourado dado como morto, 
Renée foi um dos motivadores que impediram que a protagonista tirasse a própria vida e contribuindo para o seu amadurecimento.

\section{3 - O suicídio como negação}

O suicídio infantil encontra seus extremos nas duas narrativas iniciáticas analisadas. Os jovens protagonistas realizam suas próprias jornadas em direções contrárias: Edmund em direção ao fim de sua própria vida em um ambiente onde a miséria impera e Paloma desistindo de cometer tal ato em seu luxuoso apartamento. $\mathrm{O}$ que aproxima ambas as obras de caráter tão distinto é a finalidade que impulsiona seus personagens a cogitarem dar fim a suas próprias vidas: a rejeição ao mundo dos adultos e ao futuro reservado a eles.

Em Alemanha Ano Zero, a morte do menino Edmund é o símbolo de um personagem desacreditado com os dias que estão por vir em uma cidade devastada pela guerra. $\mathrm{O}$ resultado direto de seu contato com uma sociedade corrompida. Já em $O$ Porco Espinho, Paloma não consegue entender as incoerências presentes no estilo burguês vivido por sua família. A morte, em ambos os casos, surge como a liberdade de um futuro indesejado; a interrupção de uma existência malquista.

Os adultos possuem uma importância maior do que nas narrativas iniciáticas tradicionais. Além da presença dos membros mais velhos da família, irrompem outras figuras pertencentes ao âmbito dos mais velhos e que incorporam para si a incumbência de mentores. Para Paloma essa posição é exercida pela personagem Renée Michel. Ela é uma funcionária do prédio onde a menina habita e se comporta como um contraponto a todas as atitudes que a protagonista abomina. Já para Edmund o professor irrompe como um orientador confiável em seus momentos de maior vulnerabilidade. O homem também apresenta ideais antagônicos ao visto no lar do protagonista e o auxilia a tomar decisões que culminam em sua trágica morte.

O rito percebido nessas obras não possui a estrutura convencional apontada por Van Gennep - separação, transição e reincorporação à sociedade. Ambos os protagonistas iniciam desagregados dos personagens que os cercam. A morte exerce a função de uma negação ao ato de amadurecer e continuar vivendo — decorrente de uma 
crença sobre o futuro como uma extensão da realidade que vivenciam no presente. As atitudes tomadas pelos personagens são reações ao limbo identitário que se encontram. Essa talvez seja a maior distinção entre as duas obras. Enquanto esse limbo identitário é vivido por Paloma nos primeiros minutos de projeção e é transposto ao longo da narrativa, Edmund se encontra ao final de sua história culpado pela morte de seu próprio pai, e rejeitado pelas crianças e pelos mais velhos.

As narrativas iniciáticas analisadas vão contra dois dos recorrentes mitos referentes às figuras das crianças na história do cinema:

o da inocência original das crianças, uma inocência que só se torna maculada pelo contato com a sociedade dos adultos; e a da criança-como-pai-para-o-homem, da infância como um prelúdio para o principal evento da idade adulta (CARDULLO, 2015, p. 7).

O personagem infantil não é construído nem como portador da inocência original, visto que são passíveis de serem corrompidos em seu próprio microcosmo Paloma ao matar o peixe dourado da sua irmã; e Edmund ao auxiliar outras crianças durante roubos de carregamentos —; nem como prelúdio para a idade adulto, coisa que rejeitam com a própria morte. Por essa razão, essas obras podem ser entendidas como anti-narrativas iniciáticas; uma negação à lógica do amadurecimento como sendo algo positivo, obrigatório e desejado. 


\section{CONSIDERAÇÕES FINAIS}

Mediante minhas reflexões sobre o papel da morte nas obras analisadas, penso que alcancei um dos meus principais objetivos: estabelecer debates sobre as narrativas iniciáticas e suas especificidades. O tema mórbido - ao qual fui provocado a estudar por conta de sua recorrente aparição nas criações de narrativa pelos educandos com os quais trabalhei em escolas e, até mesmo, em hospitais — rendeu seus frutos. Por meio do conceito de narrativas iniciáticas elaborado por José de Souza Miguel Lopes (2008) foi possível um recorte ainda mais específico do escopo de obras que optei em analisar. Através da discussão teórica proporcionada pelo antropólogo francês Arnold Van Gennep (1909) e sua definição de cerimônia inicial com suas três fases (separação, transição e reincorporação na sociedade), penso que consegui vislumbrar melhor a estrutura narrativa dos filmes de amadurecimento - e, por consequência, das narrativas iniciáticas. Acredito que minha pesquisa tenha sua importância exatamente por conseguir abarcar essas "entre-obras" que não se enquadram nem como filmes infantis, nem como dramas convencionais.

Estruturei em três capítulos com temas específicos: luto, crueldade infantil e suicídio - obtendo algumas conclusões em cada um deles.

No primeiro capítulo, optei por analisar obras que possuíssem a estrutura convencional das narrativas iniciáticas. As três fases de Van Gennep são bem demarcadas e a conclusão ao fim das narrativas demonstra que seus protagonistas atravessam o umbral do mundo dos adultos sem grandes complicações. A morte se apresenta pela primeira vez aos personagens e, por conta disso, o amadurecimento ocorre através do luto. Percebe-se, durante as escolhas da direção, uma separação física entre os adultos e os personagens infantis de Conta Comigo (1986) de Rob Reiner e Meu Primeiro Amor (1991) de Howard Zieff.

No segundo capítulo, a análise recai sobre a crueldade infantil que surge como resposta a um ambiente violento. As atitudes dos protagonistas consideradas pelos adultos como cruéis são analisadas sobre uma óptica moral e como resposta para uma assimilação da violência extrema que os personagens principais vivenciam. No caso de Brinquedo Proibido (1952), há mais crueldade no mundo que cerca seus protagonistas do que, propriamente, ações cruéis por parte das crianças - apenas entendida dessa 
maneira pelos personagens mais velhos da trama. As três fases de Van Gennep começam a sofrer alterações, visto que os personagens se recusam ao mundo adulto violento que os cerca. Por conta disso, durante a fase de transição, os protagonistas decidem permanecer no mundo infantil e não se reincorporar a sociedade adulta. Nas obras desse capítulo foram encontradas encarnações nomeadas por mim como polivalentes: crianças de idade próxima a dos protagonistas, mas que possuem uma fluidez para se movimentar entre o âmbito das crianças — o qual pertence - e dos adultos (o menino Michel e, de forma mais perceptível, a vampira Eli em Deixa Ela Entrar (2008)). São os polivalentes que auxiliam os protagonistas em suas trajetórias de amadurecimento e são a eles que os personagens principais procuram quando decidem permanecer no domínio infantil.

No terceiro capítulo, estudei a ocorrência do suicídio infantil como um paradigma de anti-narrativa iniciática. Nas obras analisadas, os personagens se recusam decididamente a amadurecer. Optam por dar fim a própria vida como uma forma de negação ao futuro destinado a eles. Dessa forma, ao invés de retornarem para o mundo infantil, os protagonistas se mantêm em um limbo identitário — seja decorrente da própria morte como é o caso de Edmund em Alemanha, Ano Zero (1948) ou por não ter concluído sua jornada de amadurecimento nos moldes tradicionais como Paloma em $O$ Porco Espinho (2009). Nas obras onde isso ocorre, os personagens possuem mentores adultos ao invés de polivalentes — talvez, por não possuírem a quem recorrer em sua volta para o mundo infantil, faça com que se decidam pelo suicídio (Para Sempre Lilya (2002) de Lukas Moodysson e Vuelve (2013) de Iván Noel são alguns de outros exemplos onde isso é observado). As obras são vistas como anti-narrativas iniciáticas pelo fato de seus personagens principais se recusarem a amadurecer e, com isso, transgredirem as regras desse gênero. A morte impossibilitaria a narrativa iniciática de se concretizar.

Ao final da pesquisa, penso que obtive algumas conclusões sobre o papel da morte nas narrativas iniciáticas. A principal dela é sua função-chave na trajetória do protagonista em toda obra que surge. O choque de realidade decorrente do encontro com o fim da vida impõe uma mudança em todos os protagonistas. Na estrutura tradicional, a qual eu analisei no primeiro capítulo, o amadurecimento ocorre através do encontro entre as crianças, no início de sua vida, com o óbito - podendo ocorrer tanto de maneira abrupta, como é o caso de Meu Primeiro Amor (1991), quanto como resultado 
de uma busca, como Conta Comigo (1986). Nas narrativas, esse primeiro choque com a morte desencadeia uma nova percepção da realidade pelo protagonista e sua reinserção no universo dos adultos. Nesse primeiro capítulo, o fim da vida, aparentemente distante e desconhecido, ocorre com crianças com idades próximas a dos protagonistas; o que intensifica a descoberta. Dessa forma, a constatação da finitude da existência, assim como a superação do luto, impele os protagonistas a amadurecer. Além da ausência causada pelo óbito — Gordie e seu irmão mais velho, e Vada e Thomas J. —, os protagonistas descobrem que não estão ilesos a ele.

A relação entre amadurecimento e a visão do mundo dos adultos também foi constatada. Essa visão pode ser tanto positiva, fazendo com que o personagem percorra as três fases de Van Gennep sem maiores complicações; quanto negativa, podendo a criança se decidir em permanecer no universo infantil - através de um limbo identitário ou pelo suicídio. Essas duas opções apresentadas ilustram que, nas narrativas analisadas, mostra-se inconcebível permanecer como "criança" após o contato com a morte. Os diferentes tipos de mentores (polivalente e o adulto) também se mostraram assistentes significativos para cada uma das decisões tomadas pelos personagens principais.

Possuo consciência de que, por mais que tenha escolhido obras buscando a maior variedade possível, alguns tópicos tiveram que ser suprimidos. A morte no cinema e, principalmente, as narrativas iniciáticas são temáticas com inúmeras reflexões a serem consideradas e que, sem sombra de dúvidas, não foram esgotadas com minha pesquisa.

Encaro essa minha monografia como um pontapé inicial para futuros estudos com maior aprofundamento sobre esse escopo tão diversificado de filmes que carece de material em nossa língua. Um recorte de época ou nacionalidade poderia revelar, entre outras coisas, o imaginário de infância de uma geração ou localidade. Poderíamos, por exemplo, estudar diferentes retratos do amadurecer na cinematografia mundial; ou construir um panorama de uma geração. As possibilidades são imensas e seus resultados imprevisíveis. Afinal de contas, "o cinema olha a infância e nos ensina a olhá-la" (LARROSA, LOPES e DE CASTRO TEIXEIRA, 2006, p. 12). 


\section{REFERÊNCIAS}

ABERASTURY, Arminda. A percepção da morte na criança e outros escritos. Artmed, 1984.

AIDAR, Jose Luiz; MACIEL, Márcia. O que é vampiro. Brasiliense, 1986.

ALTMAN, Rick. Film/genre. British Film Institute, 1999.

BAZIN, André. Forbidden Games. In: Bazin at Work: Major Essays and Reviews From the Forties and Fifties. Routledge, 1997.

BAZIN, André. Morte todas as tardes. A experiência do cinema. Edições Graal, 1983.

BERMAN, Helene. The relevance of narrative research with children who witness war and children who witness woman abuse. Journal of Aggression, Maltreatment \& Trauma, v. 3, n. 1, p. 107-125, 2000.

BRADFORD, Clare; HEDBERG, Lara. Bullies, the Bullied and Bullying Narratives in Contemporary Fiction. In: Cruel Children in Popular Texts and Cultures. Palgrave Macmillan, 2018.

BROMBERG, Maria Helena PF. A psicoterapia em situações de perdas e luto. Editora Psy, 1998.

CARDUllO, Bert. Neorealism, History, and The Children's Film: Vittorio de Sica's The Children Are Watching Us reconsidered. Filmhistoria online, v. 25, n. 1, p. 7-17, 2015.

CARDULLO, Bert. Of Virgin Suicide, Human Bondage, and Male Indulgence. The Hudson Review, v. 53, n. 4, p. 639-648, 2001.

DE CASTRO TEIXEIRA, Inês Assunção; LARROSA, Jorge; LOPES, José de Sousa Miguel. A infância vai ao cinema. Autêntica, 2006.

FABRIS, Mariarosaria. Neo-realismo italiano. In: História do cinema mundial. Papirus, 2006.

FELLINI, Federico. Fazer um filme. Civilização Brasileira, 2000. 
FLEGEL, Monica. Innocent Cruelty and the Love of Beauty in Oscar Wilde's Fairy

Tales. In: Cruel Children in Popular Texts and Cultures. Palgrave Macmillan, 2018.

FLEGEL, Monica; PARKES, Christopher. The Social Function of Child Cruelty. In: Cruel Children in Popular Texts and Cultures. Palgrave Macmillan, Cham, 2018.

FROTA, Ana Maria Monte Coelho. Diferentes concepções da infância e adolescência: a importância da historicidade para sua construção. Estudos e pesquisas em psicologia, v. 7, n. 1, p. 0-0, 2007.

HARDCASTLE, Anne E.; MOROSINI, Roberta; TARTE, Kendall B. (Ed.). Coming of age on film: stories of transformation in world cinema. Cambridge Scholars Pub., 2009.

KEENE, Judith. The child witness and cultural memory in European war cinema. International Journal of Media \& Cultural Politics, v. 12, n. 1, p. 95-113, 2016.

KUCZYNSKI, Evelyn. Suicídio na infância e adolescência. Psicologia USP, v. 25, n. 3, p. 246-252, 2014.

LEBEAU, Vicky. Childhood and cinema. Reaktion Books, 2008.

LOPES, José de Sousa Miguel. O cinema da infância. Revista Txt: Leituras Transdisciplinares de Telas e Textos, v. 4, n. 7, p. 22-35, 2008.

MAAS, Wilma Patricia Marzari Dinardo. O cânone mínimo: o Bildungsroman na história da literatura. Unesp, 2000.

MOINE, Raphaëlle. Cinema Genre. Blackwell Pushing, 2008.

SIQUEIRA, Romilson Martins. Do silêncio ao protagonismo: por uma leitura critica das concepções de infância e criança. Tese (Doutorado) - Universidade Federal de Goiás, Faculdade de Educação, 2011.

TURNER, Victor. O processo ritual. Petrópolis. Vozes, 1974.

VAN GENNEP, Arnold. Os Ritos de passagem: estudo sistemático dos ritos da porta e da soleira, da hospitalidade, da adoção, gravidez e parto, nascimento, infância, puberdade, iniciação, ordenação, coroação, noivado, casamento, funerais, estações, etc. Vozes, 1977 
VICENTE, João; MAGALHÃES DOS REIS, Maria da Glória. Os olhares criadores em "L’Élégance Du Hérisson" e sua transmutação fílmica. In: Anais eletrônicos do XV encontro ABRALIC - 19 a 23 de setembro de 2016, p. 4.317-4.325, 2016.

WRIGHT, Rochelle. Vampire in the Stockholm suburbs: Let the Right One In and genre hybridity. Journal of Scandinavian Cinema, v. 1, n. 1, p. 55-70, 2010. 


\section{FILMOGRAFIA}

ALEMANHA, Ano Zero. Direção de Roberto Rossellini. Itália (IT), França (FR) e Alemanha (DE): Tevere Film, SAFDI, Union Générale Cinématographique (UGC) e Deutsche Film (DEFA); 1948, 1 DVD (72 min.).

BRINQUEDO Proibido. Direção de René Clément. França (FR): Silver Films, 1952, 1 DVD (86 min.).

CONTA Comigo. Direção de Rob Reiner. Estados Unidos da América (US): Columbia Pictures Corporation, 1986, 1 DVD (89 min.).

DEIXA ela entrar. Direção de Tomas Alfredson. Suécia (SE): EFTI, Sandrew Metronome, Filmpool Nord, Sveriges Television SVT, WAG, Canal+, Fido Film AB, Ljudligan e The Chimney Pot; 2008, 1 DVD (114 min.).

MEU Primeiro Amor. Direção de Howard Zieff. Estados Unidos da América (US): Columbia Pictures Corporation e Imagine Entertainment, 1991, 1 DVD (102 min.).

O PORCO Espinho. Direção de Mona Achache. França (FR) e Itália (IT): Les Films des Tournelles, Eagle Pictures, France 2 Cinéma, Pathé e Topaze Bleue, 2009, 1 DVD (100 min.). 